\title{
Issues in the software implementation of stochastic numerical Runge-Kutta
}

\author{
Migran N. Gevorkyan,,${ }^{1, *}$ Anastasia V. Demidova, ${ }^{1, \dagger}$ Anna V. Korolkova, ${ }^{1,}{ }^{\ddagger}$ and Dmitry S. Kulyabov ${ }^{1,2, \S}$ \\ ${ }^{1}$ Department of Applied Probability and Informatics, \\ Peoples' Friendship University of Russia (RUDN University), \\ 6 Miklukho-Maklaya St, Moscow, 117198, Russian Federation \\ ${ }^{2}$ Laboratory of Information Technologies \\ Joint Institute for Nuclear Research \\ 6 Joliot-Curie, Dubna, Moscow region, 141980, Russia
}

This paper discusses stochastic numerical methods of Runge-Kutta type with weak and strong convergences for systems of stochastic differential equations in Itô form. At the beginning we give a brief overview of the stochastic numerical methods and information from the theory of stochastic differential equations. Then we motivate the approach to the implementation of these methods using source code generation. We discuss the implementation details and the used programming languages and libraries

Keywords: stochastic differential equations, stochastic numerical methods, automatic code generation, Python language, Julia language, template engine

\footnotetext{
* gevorkyan-mn@rudn.ru

$\dagger$ demidova-av@rudn.ru

‡ korolkova-av@rudn.ru

$\S$ kulyabov-ds@rudn.ru
} 


\section{INTRODUCTION}

While modeling technical systems with control it is often required to study characteristics of these systems. Also it is necessary to study the influence of system parameters on characteristics. In systems with control there is a parasitic phenomenon as self-oscillating mode. We carried out studies to determine the region of the self-oscillations emergence. However, the parameters of these oscillations were not investigated. In this paper, we propose to use the harmonic linearization method for this task. This method is used in control theory, but this branch of mathematics rarely used in classical mathematical modeling. The authors offer a methodological article in order to introduce this method to non-specialists.

\section{INTRODUCTION}

The article [1] describes the Python [2] implementation of stochastic numerical Runge-Kutta like methods. This implementations heavily relies on NumPy and SciPy [3] libraries. We chose Pyhon language because of it's simplicity and development speed. NumPy's capability to work with multidimensional arrays as tensors (functions tensor_dot and einsum) was also very helpfull. However, the performance was low, and not so much because of Python slowness, as because we used the large number of nested loops (up to seven). In this paper, we consider an alternative approach of stochastic numerical methods implementation, based on automatical code generation.

This article is divided into three sections. The first section provides an overview of the main sources and presents information from the theory of stochastic differential equations (SDE) and methods for their numerical solution. The second section presents stochastic numerical schemes for scalar SDE with strong convergence and for SDE systems with strong and weak convergence. In addition to the general schemes, several coefficient tables are provided. This allows to implement a specific numerical method. Finally, the third section explains the use of code generation for stochastic numerical methods and describes some details of the generator we have implemented (we use Jinja2 [4] template engine).

\section{BACKGROUND OVERVIEW}

In this section, we give a brief overview of the available publications on stochastic Runge-Kutta methods. We study multistage numerical schemes without partial derivatives from the drift vector $\mathbf{f}(t, \mathbf{X})$ and the diffusion matrix $\mathbf{G}(t, \mathbf{X})$, so we don't consider Milstein methods [5-7]).

First, who used a stochastic Brownian process for mathematical modeling was a French mathematician, a student of Henri Poincare - Louis J.-B. A. Bachelier (1870-1946) in 1900 in the work [8].

The book by P. E. Kloeden and E. Platen [9] is classical work about numerical methods for SDE. The book provides a brief introduction to the theory of stochastic Ito and Stratonovich differential equations and their applications. The last two thirds of the book are devoted to the presentation of numerical methods in the sense of strict and weak approximations, including a number of Runge-Kutta methods.

The dissertation by Andreas Rosler [10] is a consistent report of stochastic numerical Runge-Kutta-like methods. The author considers the approximation of Ito and Stratonovich SDE systems in a weak sense for the scalar and multidimensional Wiener process. After a brief review of the previous works, the author develops the stochastic equivalent of labelled trees theory (labelled trees are used to derive the order conditions in the case of deterministic Runge-Kutta methods, see, for example, [11, 12]).

Rossler considers weakly convergent stochastic Runge-Kutta-like methods for Ito and Stratonovich SDE systems for both the scalar and the multidimensional Wiener process. In the third and the fifth part of the dissertation describes specific implementation of the explicit stochastic numerical methods for weak convergence.

Further results of Rosler studies are described in articles $[13,14]$ in collaboration with K. Debrabant. In the preprint [14] authors continue classification of stochastic methods, Runge-Kutta method with a weak convergence. Several concrete realizations and results of numerical experiments are given. In the another preprint [15], they give tables for fourth stage and strong order convergence methods $p=3.0$.

Euler-Maruyama method described by Maruyama in the paper [16] can be considered as first stochastic RungeKutta-like method. The first systematic study of stochastic numerical Runge-Kutta-like methods of strong order of convergence $p=1.0$ is given by V. Rumelin [17] and E. Platen in his thesis [18].

Great contribution was made By P. M. Burrage and K. Burrage in a series of articles [19-23]. In these papers, they not only studied methods of strong order $p=1.5$, but also extended the theory of labeled trees to the stochastic case.

The article R. Soheili and M. Namjoo [24] obtained the three methods with strong convergence $p=1.0$ and the numerical comparison with the method from the book [9]. 
Some of the first methods with weak convergence are given in the book [9]. Further development they received in article by Komori and T. Mitsui [25] and in [26]. In the article [27] two three-stage methods, the weak convergence of the $p=2.0$, as well as numerical experiments are introduced.

In view of the extreme complexity of further improving the order of accuracy of stochastic numerical schemes, modern studies are devoted to obtaining numerical schemes for special SDE cases. It is possible to point out some of such studies about stochastic symplectic Runge-Kutta-like methods [28-30] and stochastic analogues of the Rosenbrock method [31].

\section{STOCHASTIC WIENER PROCESS AND SOFTWARE GENERATION OF ITS TRAJECTORIES}

The stochastic process $W(t), t \geqslant 0$ is called scalar Wiener process if the following conditions are true [9, 32]:

- $\mathrm{P}\{W(0)=0\}=1$, or in other words, $W(0)=0$ is almost certain;

- $W(t)$ is process with independent increments, i.e. $\left\{\Delta W_{i}\right\}_{0}^{N-1}$ are independent random variables: $\Delta W_{I}=$ $W\left(t_{I+1}\right)-W\left(t_{I}\right)$ and $0 \leqslant t_{0}<t_{1}<t_{2}<\ldots<t_{N} \leqslant T$

- $\Delta W_{i}=W\left(t_{I+1}\right)-W\left(t_{I}\right) \sim \mathcal{N}\left(0, t_{I+1}-t_{I}\right)$ where $0 \leqslant t_{I+1}<t_{I}<t, I=0,1, \ldots, N-1$

The symbol $\Delta W_{i} \sim \mathcal{N}\left(0, \Delta t_{i}\right)$ denotes that $\Delta W_{i}$ is normally distributed random variable with expected value $\mathbb{E}\left[\Delta W_{i}\right]=\mu=0$ and variance $\mathbb{D}\left[\Delta W_{i}\right]=\sigma^{2}=\Delta t_{i}$

The Wiener process is a model of Brownian motion (random walk). If we consider the process $W(t)$ in time points $0=t_{0}<t_{1}<t_{2}<\ldots<t_{N-1}<t_{N}$ when it experiences random additive changes, then directly from the definition of Wiener process follows:

$$
W\left(t_{1}\right)=W\left(t_{0}\right)+\Delta W_{0}, W\left(t_{2}\right)=W\left(t_{1}\right)+\Delta W_{1}, \ldots, W\left(t_{N}\right)=W\left(t_{N-1}\right)+\Delta W_{N-1},
$$

where $\Delta W_{i} \sim \mathcal{N}\left(0, \Delta t_{i}\right), \forall i=0, \ldots, N-1$.

If we write out $W\left(t_{N}\right)$ as cumulative sum of the increments:

$$
W\left(t_{n}\right)=W\left(t_{0}\right)+\sum_{i=0}^{n} \Delta W_{i}, \quad n=0, \ldots, N-1
$$

and $\mathbb{E}\left[\Delta W_{I}\right]=0$ and $\mathbb{D}\left[\Delta W_{i}\right]=\Delta t_{I}$, then we can show that the sum of normally distributed random numbers $\Delta W_{I}$ is also a normally distributed random number:

$$
\mathbb{E} \sum_{i=0}^{N} \Delta W_{i}=0, \quad \mathbb{D} \sum_{i=0}^{n} \Delta W_{i}=\sum_{i=0}^{n} \Delta t_{i}=t_{n}-t_{0}, \sum_{i=0}^{n} \Delta W_{i} \sim \mathcal{N}\left(0, t_{n}-t_{0}\right)
$$

The multidimensional Wiener process $\mathbf{W}(t): \Omega \times\left[t_{0}, T\right] \rightarrow \mathbb{R}^{m}$ is defined as a random process composed of jointly independent one-dimensional Wiener processes $W^{1}(t), \ldots, W^{m}(t)$. Increments of $\Delta W_{I}^{\alpha}, \forall \alpha=1, \ldots, m$ are jointly independent normally distributed random variables. On the other hand, the vector $\Delta W_{I}^{\alpha}$ can be represented as a multidimensional normally distributed random variable with the expectation vector $\mu=\mathbf{0}$ and the diagonal covariance matrix.

In the case of a multidimensional stochastic process one has to generate $m$ sequences of $n$ normally distributed random variables should be generated.

\section{STOCHASTIC INTEGRALS AND SDE FOR SCALAR WIENER PROCESS}

The definition of the stochastic differential equation begins with the definition of the stochastic integrals.

Let $g(t, x(t))$ be a continuous scalar function depending on the random process $x(t)$, $W(t)$ is Wiener process, $t \in\left[t_{0}, T\right], 0 \leqslant t_{0}<t_{1}<t_{2}<\ldots<t_{n-1}<t_{n} \leqslant T<\infty$ are time points on segment $\left[t_{0}, T\right]$, then

$$
I(\theta)=\int_{t_{0}}^{T} g(t, x(t)) \mathrm{d} W(t)=\underset{n \rightarrow \infty}{\lim .} \sum_{i=0}^{n-1} g\left(\theta t_{i+1}+(1-\theta) t_{i}, \theta x\left(t_{i+1}\right)+(1-\theta) x\left(t_{i}\right)\right)\left(W\left(t_{i+1}\right)-W\left(t_{i}\right)\right)
$$

where $\theta \in[0,1] . I(\theta)$ is called stochastic integral. For a more strict definition of stochastic integrals for a wide class of functions, see [32, Chapter 3].

In physics and applied mathematics, two special cases of stochastic integrals are used: 
- Ito integrals (named in honor the Japanese mathematician K. Ito)

$$
I=I(0)=\lim _{n \rightarrow \infty} \sum_{i=0}^{n-1} g\left(t_{i}, x\left(t_{i}\right)\right)\left(W\left(t_{i+1}\right)-W\left(t_{i}\right)\right),
$$

- Stratonovich integrals (named in honor of the soviet physicist R. L. Stratonovich)

$$
I_{0.5}=I(0.5)=\operatorname{lifim}_{n \rightarrow \infty} \sum_{i=0}^{n-1} g\left(\frac{t_{i+1}+t_{i}}{2}, \frac{x\left(t_{i+1}\right)+x\left(t_{i}\right)}{2}\right)\left(W\left(t_{i+1}\right)-W\left(t_{i}\right)\right) .
$$

After defining stochastic integrals, we can introduce the integral equation for the stochastic process $x(t)$ [32].

$$
x\left(t_{k}\right)=x\left(t_{0}\right)+\int_{0}^{t} f(\tau, x(\tau)) \mathrm{d} \tau+\underbrace{\int_{0}^{t} g(\tau, x(\tau)) \mathrm{d} W .}_{\text {stochastic integral }}
$$

The above integral equation corresponds to the stochastic differential equation (SDE):

$$
\mathrm{d} x(t)=f(t, x(t)) \mathrm{d} t+g(t, x(t)) \mathrm{d} W .
$$

It should be noted that the differential $\mathrm{d} x$ is not a usual "small" increment of function $x(t)$, but is a random variable. It can be treated as symbolic notation of the limit of the iterative scheme. The Wiener process $W(t)$, whose increments are part of the SDE, is called the driving process for a given SDE.

\section{ITO SDE FOR MULTIDIMENSIONAL WIENER PROCESS}

Let us consider the probabilistic space $(\Omega, \dashv, \mathbb{P})$, where $\Omega$ is the space of elementary events, $\mathcal{A}$ is sigma-algebra of subsets of the space $\Omega, \mathbb{P}$ is probabilistic measure. The variable $t$ from the interval $\left[t_{0}, T\right] \in \mathbb{R}^{1}$ has physical sense of time.

Consider the random process $\mathbf{x}(t)=\left(x^{1}(t), \ldots, x^{d}(t)\right)^{T}$, where $\mathbf{x}(t)$ belongs to the functional space $\mathrm{L}^{2}(\Omega)$ with the norm $\|\cdot\|$. We assume that the random process $\mathbf{x}(t)$ is a solution for the Ito $\operatorname{SDE}[9,32]$ if:

$$
\mathbf{x}(t)=\mathbf{f}(t, \mathbf{x}(t)) \mathrm{d} t+\mathbf{G}(t, \mathbf{x}(t)) \mathrm{d} \mathbf{W},
$$

where $\mathbf{W}=\left(W^{1}, \ldots, W^{m}\right)^{T}$ is multidimensional Wiener process, known as driving process for SDE. The function $\mathbf{f}:\left[t_{0}, T\right] \times \mathbb{R}^{d} \rightarrow \mathbb{R}^{d}$ is called drift vector, and the matrix-valued function $\mathbf{G}:\left[t_{0}, T\right] \times \mathbb{R}^{d} \times \mathbb{R}^{m} \rightarrow \mathbb{R}^{d} \times \mathbb{R}^{m}$ is called diffusion matrix. In addition, $\mathbf{f}(t, \mathbf{x}(t))=\left(f^{1}(t, \mathbf{x}), \ldots, f^{d}(t, \mathbf{x})^{t}\right.$, and the $\mathbf{G}$ matrix looks like:

$$
\mathbf{G}=\left[\begin{array}{cccc}
g_{1}^{1}(t, \mathbf{x}) & g_{2}^{1}(t, \mathbf{x}) & \ldots & g_{m}^{1}(t, \mathbf{x}) \\
g_{1}^{2}(t, \mathbf{x}) & g_{2}^{2}(t, \mathbf{x}) & \ldots & g_{m}^{2}(t, \mathbf{x}) \\
\vdots & \vdots & \ddots & \vdots \\
g_{1}^{d}(t, \mathbf{x}) & g_{2}^{d}(t, \mathbf{x}) & \ldots & g_{m}^{d}(t, \mathbf{x})
\end{array}\right]
$$

The same equation can be rewritten in indexed form

$$
x^{\alpha}(t)=f^{\alpha}\left(t, x^{\gamma}(t)\right) \mathrm{d} t+\sum_{\beta=1}^{m} g_{\beta}^{\alpha}\left(t, x^{\gamma}(t)\right) \mathrm{d} W^{\beta},
$$

where $\alpha, \gamma=1, \ldots, d, \beta=1, \ldots, m$, and $f^{\alpha}\left(t, x^{\gamma}(t)\right)=f^{\alpha}\left(t, x^{1}(t), \ldots, x^{d}(t)\right)$.

On the interval $\left[t_{0}, T\right]$, we introduce the grid $t_{0}<t_{1}<\ldots<t_{N}=T$ with step $h_{n}=t_{n+1}-t_{n}$, where $n=0, \ldots, N-1$ and the maximum grid step $h=\max \left\{h_{n-1}\right\}_{1}^{N}$. Next, we assume that the grid is uniform, then $h_{n}=h=$ const. $\mathbf{x}_{n}$ is grid function, which approximate a stochastic process $\mathbf{x}(t)$, so $\mathbf{x}_{0}=\mathbf{x}\left(t_{0}\right), \mathbf{x}_{n} \approx \mathbf{x}\left(t_{n}\right) \forall n=1, \ldots, N$. 


\section{CALCULATION AND APPROXIMATION OF MULTIPLE ITO INTEGRALS OF SPECIAL FORM}

Here we will not go into the general theory of multiple stochastic Ito integrals, a reader can refer to the book [9] for additional information. Here we consider multiple special integrals, which are included in the stochastic numerical schemes.

In General, for the construction of numerical schemes with order of convergence greater than $p=\frac{1}{2}$, it is necessary to calculate single, double and triple Ito integrals of the following form:

$$
\begin{gathered}
I^{\alpha}\left(t_{n}, t_{n+1}\right)=I^{\alpha}\left(h_{n}\right)=\int_{t_{n}}^{t_{n+1}} \mathrm{~d} W^{\alpha}(\tau), \\
I^{\alpha \beta}\left(t_{n}, t_{n+1}\right)=I^{\alpha \beta}\left(h_{n}\right)=\int_{t_{n}}^{t_{n+1}} \int_{t_{n}}^{\tau_{1}} \mathrm{~d} W^{\alpha}\left(\tau_{2}\right) \mathrm{d} W^{\beta}\left(\tau_{1}\right), \\
I^{\alpha \beta \gamma}\left(t_{n}, t_{n+1}\right)=I^{\alpha \beta \gamma}\left(h_{n}\right)=\int_{t_{n}}^{t_{n+1}} \int_{t_{n}}^{\tau_{1}} \int_{t_{n}}^{\tau_{2}} \mathrm{~d} W^{\alpha}\left(\tau_{3}\right) \mathrm{d} W^{\beta}\left(\tau_{2}\right) \mathrm{d} W^{\gamma}\left(\tau_{1}\right),
\end{gathered}
$$

where $\alpha, \beta, \gamma=0 \ldots, m$ and $W^{\alpha}, \alpha=1, \ldots, m$ are components of multidimensional Wiener process. In the case of $\alpha, \beta, \gamma=0$, the increment of $\mathrm{d} W^{0}(\tau)$ is assumed to be $\mathrm{d} \tau$.

The problem is to get analytical formulas for these integrals with $\Delta W_{n}^{I}=W^{I}\left(t_{n+1}\right)-W^{I}\left(t_{n}\right)$ in them. Despite its apparent simplicity, this is not achievable for all possible combinations of indices. Let us consider in the beginning those cases when it is possible to obtain an analytical expression, and then turn to those cases when it is necessary to use an approximating formulas.

In the case of a single integral, the problem is trivial and the analytic expression can be obtained for any index $\alpha$ :

$$
I^{0}\left(h_{n}\right)=\Delta t_{n}=h_{n}, \quad I^{\alpha}\left(h_{n}\right)=\Delta W_{n}^{\alpha}, \alpha=1, \ldots, m
$$

In the case of a double integral $I^{\alpha \beta}\left(h_{n}\right)$, the exact formula takes place only at $\alpha=\beta$ :

$$
I^{00}\left(h_{n}\right)=\frac{1}{2} \Delta t_{n}=\frac{1}{2} h_{n}^{2}, \quad I^{\alpha \alpha}\left(h_{n}\right)=\frac{1}{2}\left(\left(\Delta W_{n}^{\alpha}\right)^{2}-\Delta t_{n}\right), \alpha=1, \ldots, m,
$$

in other cases, when $\alpha \neq \beta$ Express $I^{\alpha \beta}\left(h_{n}\right)$ by increments of $\Delta W_{n}^{\alpha}$ and $\Delta t_{n}$ in the final form is not possible, so we can only use numerical approximation.

For the mixed case $I^{0 \alpha}$ and $I^{\alpha 0}$ in [10], simple formulas of the following form are given:

$$
\begin{aligned}
& I^{0 \alpha}\left(h_{n}\right)=\frac{1}{2} h_{n}\left(I^{\alpha}\left(h_{n}\right)-\frac{1}{\sqrt{3}} \zeta^{\alpha}\left(h_{n}\right)\right), \\
& I^{\alpha 0}\left(h_{n}\right)=\frac{1}{2} h_{n}\left(I^{\alpha}\left(h_{n}\right)+\frac{1}{\sqrt{3}} \zeta^{\alpha}\left(h_{n}\right)\right),
\end{aligned}
$$

where $\zeta_{n}^{\alpha} \sim \mathcal{N}\left(0, h_{n}\right)$ are multidimensional normal distributed random variables.

For the General case $\alpha, \beta=1, \ldots, m$, the book [9] provides the following formulas for approximating the double Ito integral $I^{\alpha \beta}$ :

$$
\begin{gathered}
I^{\alpha \beta}\left(h_{n}\right)=\frac{\Delta W_{n}^{\alpha} \Delta W_{n}^{\beta}-h_{n} \delta^{\alpha \beta}}{2}+A^{\alpha \beta}\left(h_{n}\right), \\
A^{\alpha \beta}\left(h_{n}\right)=\frac{h}{2 \pi} \sum_{k=1}^{\infty} \frac{1}{k}\left[V_{k}^{\alpha}\left(U_{k}^{\beta}+\sqrt{\frac{2}{h_{n}}} \Delta W_{n}^{\beta}\right)-V_{k}^{\beta}\left(U_{k}^{\alpha}+\sqrt{\frac{2}{h_{n}}} \Delta W_{n}^{\alpha}\right)\right],
\end{gathered}
$$

where $V_{k}^{\alpha} \sim \mathcal{N}(0,1), U_{k}^{\alpha} \sim \mathcal{N}(0,1), \alpha=1, \ldots, m ; k=1, \ldots, \infty ; n=1, \ldots, N$ is numerical schema number. From the formulas it is seen that in the case $\alpha=\beta$, we get the final expression for the $I^{\alpha \beta}$, which we mentioned above. In the 
case of $\alpha \neq \beta$, one has to sum the infinite series $a^{\alpha \beta}$. This algorithm gives an approximation error of order $O\left(h^{2} / n\right)$, where $n$ is number of left terms of an infinite series $a^{i j}$.

In the article [33] a matrix form of approximating formulas is introduced. Let $\mathbf{1}_{m \times m}, \mathbf{0}_{m \times m}$ be the unit and zero matrices $m \times m$, then

$$
\begin{gathered}
\mathbf{I}\left(h_{n}\right)=\frac{\Delta \mathbf{W}_{n} \Delta \mathbf{W}_{n}^{T}-h_{n} \mathbf{1}_{m \times m}}{2}+\mathbf{A}\left(h_{n}\right), \\
\mathbf{A}\left(h_{n}\right)=\frac{h}{2 \pi} \sum_{k=1}^{\infty} \frac{1}{k}\left(\mathbf{V}_{k}\left(\mathbf{U}_{k}+\sqrt{2 / h_{n}} \Delta \mathbf{W}_{n}\right)^{T}-\left(\mathbf{U}_{k}+\sqrt{2 / h_{n}} \Delta \mathbf{W}_{n}\right) \mathbf{V}_{k}^{T}\right),
\end{gathered}
$$

where $\Delta \mathbf{W}_{n}, \mathbf{V}_{k}, \mathbf{U}_{k}$ are independent normally distributed multidimensional random variables:

$$
\begin{gathered}
\Delta \mathbf{W}_{n}=\left(\Delta W_{n}^{1}, \Delta W_{n}^{2}, \ldots, \Delta W_{n}^{m}\right)^{T} \sim \mathcal{N}\left(\mathbf{0}_{m \times m}, h_{n} \mathbf{1}_{m \times m}\right), \\
\mathbf{V}_{k}=\left(V_{k}^{1}, V_{k}^{2}, \ldots, V_{k}^{m}\right)^{T} \sim \mathcal{N}\left(\mathbf{0}_{m \times m}, \mathbf{1}_{m \times m}\right), \quad \mathbf{U}_{k}=\left(U_{k}^{1}, U_{k}^{2}, \ldots, U_{k}^{m}\right)^{T} \sim \mathcal{N}\left(\mathbf{0}_{m \times m}, \mathbf{1}_{m \times m}\right) .
\end{gathered}
$$

If the programming language supports vectored operations with multidimensional arrays, these formulas can provide a benefit to the performance of the program.

Finally, consider a triple integral. In the only numerical scheme in which it occurs, it is necessary to be able to calculate only the case of identical indexes $\alpha=\beta=\gamma$. For this case, [10] gives the following formula:

$$
I^{\alpha \alpha \alpha}\left(h_{n}\right)=\frac{1}{6}\left(\left(I^{\alpha}\left(h_{n}\right)\right)^{3}-3 I^{0}\left(h_{n}\right) I^{\alpha}\left(h_{n}\right)\right)=\frac{1}{6}\left(\left(\Delta W_{n}^{\alpha}\right)^{3}-3 h_{n} \Delta W_{n}^{\alpha}\right) .
$$

\section{STRONG AND WEAK CONVERGENCE OF THE APPROXIMATING FUNCTION}

Before proceeding to the formulation of numerical schemes, it is necessary to determine the criterion of accuracy of approximation of the simulated process $\mathbf{x}(t)$ by the grid function $\mathbf{x}_{n}$. Two criteria are used: weak and strong convergence.

The sequence of approximating functions $\left\{\mathbf{x}_{n}\right\}_{1}^{N}$ converges with order $p$ to the exact solution $\mathbf{x}(t)$ of SDE in moment $T$ in strong sense if constant $C>0$ exists and $\delta_{0}>0$ such as $\forall h \in\left(0, \delta_{0}\right.$ and following condition is fulfilled:

$$
\left(\left\|\mathbf{x}(T)-\mathbf{x}_{N}\right\|\right) \leqslant C h^{p} .
$$

The sequence of approximating functions $\left\{\mathbf{x}_{n}\right\}_{1}^{N}$ converges with order $p$ to the exact solution $\mathbf{x}(t)$ of SDE in moment $T$ in weak sense if constant $C_{F}>0$ exists and $\delta_{0}>0$ such as $\forall h \in\left(0, \delta_{0}\right]$ and the following condition is fulfilled:

$$
\left|\mathbb{E}[F(\mathbf{x}(T))]-\mathbb{E}\left[F\left(\mathbf{x}_{N}\right)\right]\right| \leqslant C_{F} h^{p} .
$$

Here $F \in C_{\mathrm{P}}^{2(p+1)}\left(\mathbb{R}, \mathbb{R}^{d}\right)$ is a continuous differentiable functional with polynomial growth.

If the $\mathbf{G}$ matrix is zero, then the strong convergence condition is equivalent to the deterministic case, but the order of strong convergence is not necessarily a natural number and can take fractional-rational values.

It is important to note that the choice of the convergence type depends on the problem one has to solve. Increasing the order of strict convergence leads to more accurate approximation of the trajectories of $\mathbf{x}(t)$. If one wants to calculate, for example, the moment of a random process $\mathbf{x}(t)$ or a generalized functional of the form $\mathbb{E}[F(\mathbf{x}(t))]$, one should increase the order of weak convergence.

\section{STOCHASTIC RUNGE-KUTTA-LIKE NUMERICAL METHODS}

\section{A. Euler-Maruyama numerical method}

The simplest numerical method for solving scalar equations and systems of SDEs is the Euler-Maruyama method, named in honor of Gisiro Maruyama, which extended the classical Euler method for ODEs to the case of equation [16]. The method is easily generalized to the case of multidimensional Wiener process.

$$
x_{0}^{\alpha}=x^{\alpha}\left(t_{0}\right),
$$




$$
x_{n+1}^{\alpha}=x_{n}^{\alpha}+f^{\alpha}\left(t_{n}, x_{n}^{\alpha}\right) h_{n}+\sum_{\gamma=1}^{d} G_{\beta}^{\alpha}\left(t_{n}, x_{n}^{\gamma}\right) \Delta W_{n}^{\beta} .
$$

From the formula we can see, that each step requires only corresponding to this step increment $\Delta W_{n}^{\beta}$. The method has a strong order $\left(p_{d}, p_{s}\right)=(1.0,0.5)$. The value $p_{d}$ denotes the deterministic accuracy order, when the method is used for the equation with $G\left(t, x^{\alpha}(t)\right) \equiv 0$. The value $p_{s}$ denotes the stochastic part approximation order.

\section{B. Weak stochastic Runge-Kutta-like method with order 1.5 for a scalar Wiener process}

In the case of a scalar SDE, the drift vector $f^{\alpha}\left(t, x^{\gamma}\right)$ and the diffusion matrix $G_{\beta}^{\alpha}\left(t, x^{\gamma}\right)$ become $f(t, x)$ and $g(t, x)$ scalar functions, and the driving Wiener process $W_{t}^{\beta}$ is scalar $W_{t}$. For scalar SDE it is possible to construct a numerical scheme with strong convergence $p=1.5$ :

$$
\begin{aligned}
X_{0}^{i}= & x_{n}+\sum_{j=1}^{s} A_{0 j}^{i} f\left(t_{n}+c_{0}^{j} h_{n}, X_{0}^{j}\right) h_{n}+\sum_{j=1}^{s} B_{0 j}^{i} g\left(t_{n}+c_{1}^{j} h_{n}, X_{1}^{j}\right) \frac{I^{10}\left(h_{n}\right)}{\sqrt{h_{n}}}, \\
X_{1}^{i}= & x_{n}+\sum_{j=1}^{s} A_{1 j}^{i} f\left(t_{n}+c_{0}^{j} h_{n}, X_{0}^{j}\right) h_{n}+\sum_{j=1}^{s} B_{1 j}^{i} g\left(t_{n}+c_{1}^{j} h_{n}, X_{1}^{j}\right) \sqrt{h_{n}}, \\
x_{n+1} & =x_{n}+\sum_{i=1}^{s} a_{i} f\left(t_{n}+c_{0}^{i} h_{n}, X_{0}^{i}\right) h_{n}+ \\
& +\sum_{i=1}^{s}\left(b_{i}^{1} I^{1}\left(h_{n}\right)+b_{i}^{2} \frac{I^{11}\left(h_{n}\right)}{\sqrt{h_{n}}}+b_{i}^{3} \frac{I^{10}\left(h_{n}\right)}{h_{n}}+b_{i}^{4} \frac{I^{111}\left(h_{n}\right)}{h_{n}}\right) g\left(t_{n}+c_{1}^{i} h_{n}, X_{1}^{i}\right),
\end{aligned}
$$

where $i, j=1, \ldots, s$ ( $s$ is numbers of method's stages). The generalized Butcher table [15] has fallowing form:

$$
\begin{array}{c|c|c|c}
c_{0}^{i} & A_{0 j}^{i} & B_{0 j}^{i} & \\
\hline c_{1}^{i} & A_{1 j}^{i} & B_{1 j}^{i} & \\
\hline & a_{i} & b_{i}^{1} & b_{i}^{2} \\
\hline & & b_{i}^{3} & b_{i}^{4}
\end{array}
$$

In the above numerical scheme, the Wiener stochastic process is present in implicit way. It is "hidden" inside the stochastic Ito integrals: $I^{10}\left(h_{n}\right), I^{1}\left(h_{n}\right), I^{11}\left(h_{n}\right), I^{111}\left(h_{n}\right)$. For scalar case they are simplified:

$$
\begin{aligned}
& I^{1}\left(h_{n}\right)=\Delta W_{n}, \\
& I^{10}\left(h_{n}\right)=\frac{1}{2} h_{n}\left(\Delta W_{n}+\zeta_{n} / \sqrt{3}\right), \\
& I^{11}\left(h_{n}\right)=\frac{1}{2}\left(\left(\Delta W_{n}\right)^{2}-h_{n}\right), \\
& I^{111}\left(h_{n}\right)=\frac{1}{6}\left(\left(\Delta W_{n}\right)^{3}-h_{n} \Delta W_{n}\right),
\end{aligned}
$$

where $\zeta_{n} \sim \mathcal{N}\left(0, h_{n}\right), \sigma=\sqrt{h_{n}}$ 
Rossler introduce two Butcher tables for strong scalar methods in preprint [15] for $s=4$

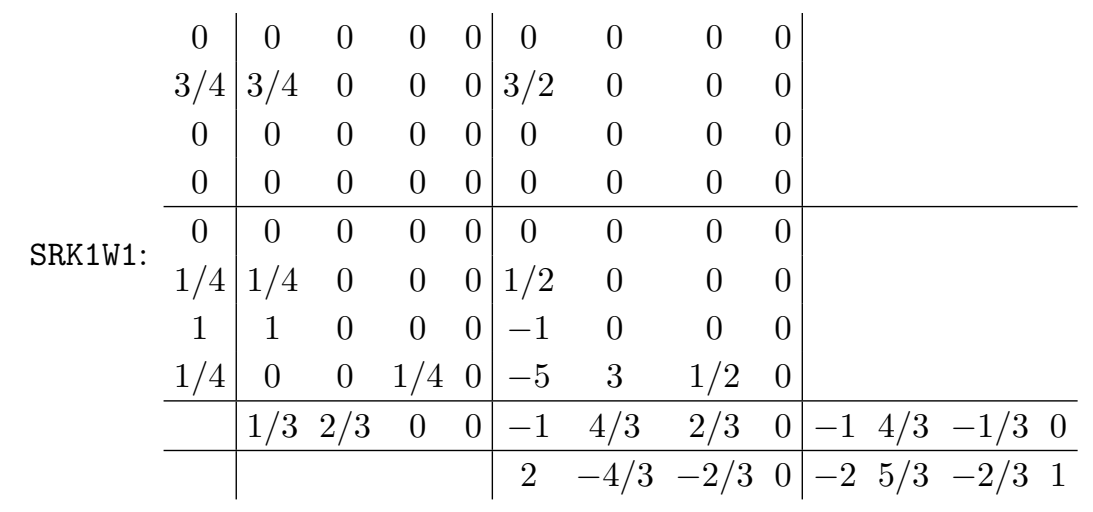

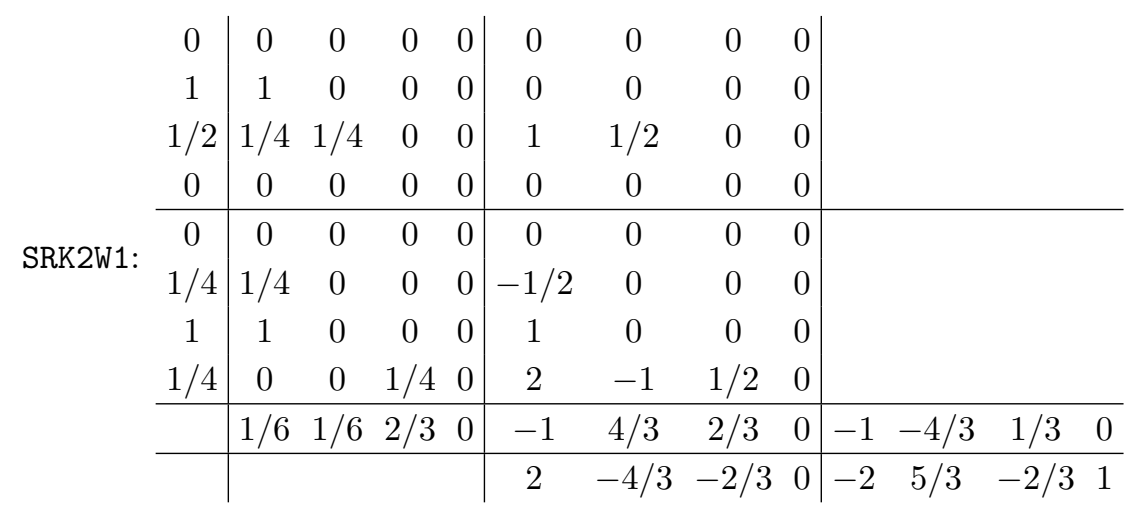

The numerical schema for the first table we denote as SRK1W1 and the second as SRK2W2. Methods SRK1W1 and SRK2W1 have strong orders $\left(p_{d}, p_{s}\right)=(2.0,1.5)$ and $\left(p_{d}, p_{s}\right)=(3.0,1.5)$ respectively. One more method $p_{s}=1.0$ is introduced in book [9] and its Butcher table has the following form:

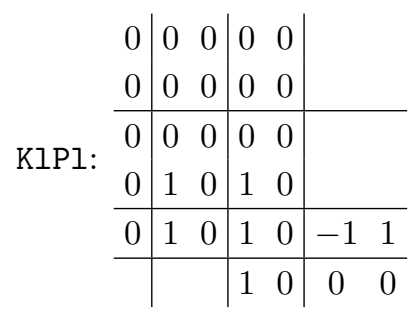

\section{Stochastic Runge-Kutta method with strong order $p=1.0$ for vector Wiener process}

For SDE system with a multidimensional Wiener process, one can construct a stochastic numerical Runge-Kutta scheme of strong order $p_{s}=1.0$ using single and double Ito integrals [15].

$$
\begin{aligned}
& X^{0 i \alpha}=x_{n}^{\alpha}+\sum_{j=1}^{s} A_{0 j}^{i} f^{\alpha}\left(t_{n}+c_{0}^{j} h_{n}, X^{0 j \beta}\right) h_{n}+\sum_{l=1}^{m} \sum_{j=1}^{s} B_{0 j}^{i} G_{l}^{\alpha}\left(t_{n}+c_{1}^{j} h_{n}, X^{l j \beta}\right) I^{l}\left(h_{n}\right), \\
& X^{k i \alpha}=x_{n}^{\alpha}+\sum_{j=1}^{s} A_{1 j}^{i} f^{\alpha}\left(t_{n}+c_{0}^{j} h_{n}, X^{0 j \beta}\right) h_{n}+\sum_{l=1}^{m} \sum_{j=1}^{s} B_{1 j}^{i} G_{l}^{\alpha}\left(t_{n}+c_{1}^{j} h_{n}, X^{l j \beta}\right) \frac{I^{l k}\left(h_{n}\right)}{\sqrt{h_{n}}}, \\
& x_{n+1}^{\alpha}=x_{n}^{\alpha}+\sum_{i=1}^{s} a_{i} f^{\alpha}\left(t_{n}+c_{0}^{i} h_{n}, X^{0 i \beta}\right) h_{n}+\sum_{k=1}^{m} \sum_{i=1}^{s}\left(b_{i}^{1} I^{k}\left(h_{n}\right)+b_{i}^{2} \sqrt{h_{n}}\right) G_{k}^{\alpha}\left(t_{n}+c_{1}^{i} h_{n}, X^{k i \beta}\right),
\end{aligned}
$$


$n=0,1, \ldots, N-1 ; i=1, \ldots, s ; \beta, k=1, \ldots, m ; \alpha=1, \ldots, d$. Its generalized Butcher table has the following form [15]:

$$
\begin{array}{c|c|c|c}
c_{0}^{i} & A_{0 j}^{i} & B_{0 j}^{i} & \\
\hline c_{1}^{i} & A_{1 j}^{i} & B_{1 j}^{i} & \\
\hline & a_{i} & b_{i}^{1} & b_{i}^{2}
\end{array}
$$

Rossler introduce two Butcher tables for strong scalar methods in preprint [15] for $s=3$

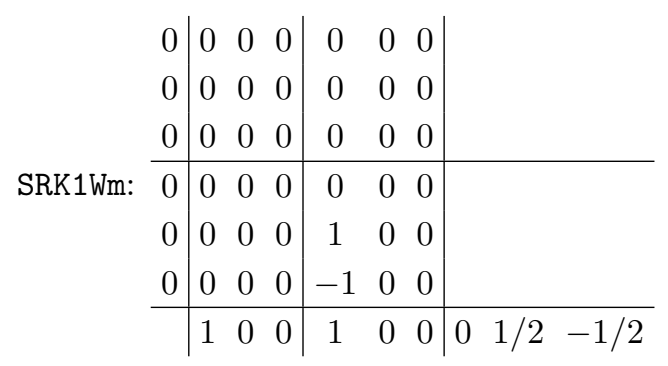

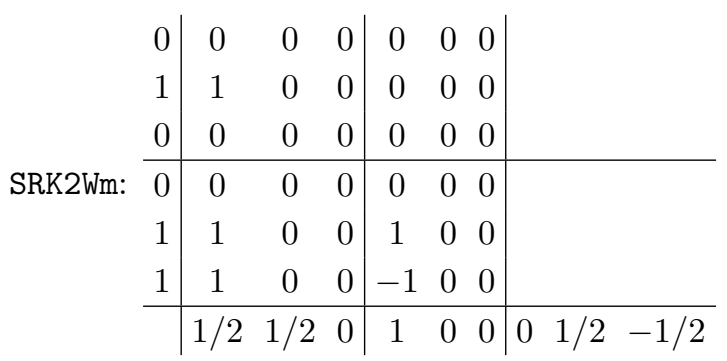

Methods SRK1Wm and SRK2Wm have strong order $\left(p_{d}, p_{s}\right)=(1.0,1.0)$ and $\left(p_{d}, p_{s}\right)=(2.0,1.0)$.

\section{Stochastic Runge-Kutta method with weak order $p=2.0$ for vector Wiener process}

Numerical methods with weak convergence are good for approximation the distribution characteristics of stochastic process $x^{\alpha}(t)$. The weak numerical method does not need information about the trajectory of driving Wiener process $W_{n}^{\alpha}$ and random increments for these methods can be generated on another probability space.

$$
\begin{aligned}
& X^{0 i \alpha}=x_{n}^{\alpha}+\sum_{j=1}^{s} A_{0 j}^{i} f^{\alpha}\left(t_{n}+c_{0}^{j} h_{n}, X^{0 j \beta}\right) h_{n}+\sum_{j=1}^{s} \sum_{l=1}^{m} B_{0 j}^{i} G_{l}^{\alpha}\left(t_{n}+c_{1}^{j} h_{n}, X^{l j \beta}\right) \hat{I}^{l}, \\
& X^{k i \alpha}=x_{n}^{\alpha}+\sum_{j=1}^{s} A_{1 j}^{i} f^{\alpha}\left(t_{n}+c_{0}^{j} h_{n}, X^{0 j \beta}\right) h_{n}+\sum_{j=1}^{s} B_{1 j}^{i} G_{k}^{\alpha}\left(t_{n}+c_{1}^{j} h_{n}, X^{k j \beta}\right) \sqrt{h_{n}}, \\
& \widehat{X}^{k i \alpha}=x_{n}^{\alpha}+\sum_{j=1}^{s} A_{2 j}^{i} f^{\alpha}\left(t_{n}+c_{0}^{j} h_{n}, X^{0 j \beta}\right) h_{n}+\sum_{j=1}^{s} \sum_{l=1, l \neq k}^{m} B_{2 j}^{i} G_{l}^{\alpha}\left(t_{n}+c_{1}^{j} h_{n}, X^{l j \beta}\right) \frac{\hat{I}^{k l}}{\sqrt{h_{n}}} \\
& x_{n+1}^{\alpha}=x_{n}^{\alpha}+\sum_{i=1}^{s} a_{i} f^{\alpha}\left(t_{n}+c_{0}^{i}, X^{0 i \beta}\right) h_{n}+\sum_{i=1}^{s} \sum_{k=1}^{m}\left(b_{i}^{1} \hat{I}^{k}+b_{i}^{2} \frac{\hat{I}^{k k}}{\sqrt{h_{n}}}\right) G_{k}^{\alpha}\left(t_{n}+c_{1}^{i} h_{n}, X^{k i \beta}\right)+ \\
& +\sum_{i=1}^{s} \sum_{k=1}^{m}\left(b_{i}^{3} \hat{I}^{k}+b_{i}^{4} \sqrt{h_{n}}\right) G_{k}^{\alpha}\left(t_{n}+c_{2}^{i} h_{n}, \widehat{X}^{k i \beta}\right)
\end{aligned}
$$


Generalized Butcher table has the following form [15]

\begin{tabular}{c|c|c|c}
$c_{0}^{i}$ & $A_{0 j}^{i}$ & $B_{0 j}^{i}$ & \\
\hline$c_{1}^{i}$ & $A_{1 j}^{i}$ & $B_{1 j}^{i}$ & \\
\hline$c_{2}^{i}$ & $A_{2 j}^{i}$ & $B_{2 j}^{i}$ & \\
\hline & $a_{i}$ & $b_{i}^{1}$ & $b_{i}^{2}$ \\
\hline & & $b_{i}^{3}$ & $b_{i}^{4}$
\end{tabular}

From the paper [14] we get two Butcher tables:

\begin{tabular}{|c|c|c|c|c|c|c|c|}
\hline 0 & 0 & 0 & 0 & 0 & 0 & 0 & \\
\hline 1 & 1 & 0 & 0 & $\frac{1}{3}$ & 0 & 0 & \\
\hline$\frac{5}{12}$ & $\frac{25}{144}$ & $\frac{35}{144}$ & 0 & $-\frac{5}{6}$ & 0 & 0 & \\
\hline 0 & 0 & 0 & 0 & 0 & 0 & 0 & \\
\hline$\frac{1}{4}$ & $\frac{1}{4}$ & 0 & 0 & $\frac{1}{2}$ & 0 & 0 & \\
\hline$\frac{1}{4}$ & $\frac{1}{4}$ & 0 & 0 & $-\frac{1}{2}$ & 0 & 0 & \\
\hline 0 & 0 & 0 & 0 & 0 & 0 & 0 & \\
\hline 0 & 0 & 0 & 0 & 1 & 0 & 0 & \\
\hline \multirow[t]{3}{*}{0} & 0 & 0 & 0 & -1 & 0 & 0 & \\
\hline & $\frac{1}{10}$ & $\frac{3}{14}$ & $\frac{24}{35}$ & 1 & -1 & -1 & $\begin{array}{lll}0 & 1 & -1\end{array}$ \\
\hline & & & & & & $-\frac{1}{4}$ & $\begin{array}{lll}0 & \frac{1}{2} & -\frac{1}{2}\end{array}$ \\
\hline
\end{tabular}

\begin{tabular}{|c|c|c|c|c|c|}
\hline & $\begin{array}{ll}0 & 0\end{array}$ & & 0 & $\begin{array}{ll}0 & 0\end{array}$ & \\
\hline & 10 & & 1 & $\begin{array}{ll}0 & 0\end{array}$ & \\
\hline U & $\begin{array}{ll}0 & 0 \\
\end{array}$ & 0 & 0 & $\begin{array}{ll}0 & 0\end{array}$ & \\
\hline 0 & $\begin{array}{ll}0 & 0\end{array}$ & & 0 & $\begin{array}{ll}0 & 0\end{array}$ & \\
\hline 1 & 10 & & 1 & $\begin{array}{ll}0 & 0\end{array}$ & \\
\hline 1 & $\begin{array}{ll}1 & 0 \\
\end{array}$ & 0 & -1 & $\begin{array}{ll}0 & 0\end{array}$ & \\
\hline 0 & $\begin{array}{|ll|}0 & 0\end{array}$ & & 0 & $\begin{array}{ll}0 & 0\end{array}$ & \\
\hline 0 & $\begin{array}{ll}0 & 0\end{array}$ & & 1 & $\begin{array}{ll}0 & 0\end{array}$ & \\
\hline 0 & $\begin{array}{ll}0 & 0 \\
\end{array}$ & $0-$ & -1 & $\begin{array}{ll}0 & 0\end{array}$ & \\
\hline & $\begin{array}{ll}\frac{1}{2} & \frac{1}{2} \\
\end{array}$ & & $\frac{1}{2} \quad \frac{1}{2}$ & $\begin{array}{ll}\frac{1}{4} & \frac{1}{4} \\
\end{array}$ & $0 \quad \frac{1}{2}-\frac{1}{2}$ \\
\hline
\end{tabular}

In the weak numerical schema $\hat{I}^{k l}$ are

$$
\hat{I}^{k l}=\left\{\begin{array}{l}
\frac{1}{2}\left(\hat{I}^{k} \hat{I}^{l}-\sqrt{h}_{n} \tilde{I}^{k}\right), k<l, \\
\frac{1}{2}\left(\hat{I}^{k} \hat{I}^{l}+\sqrt{h}_{n} \tilde{I}^{l}\right), l<k, \\
\frac{1}{2}\left(\left(\hat{I}^{k}\right)^{2}-h_{n}\right) . k=l .
\end{array}\right.
$$

Where $\hat{I}^{k}$ denotes three point distributed random variable. It means, that $\hat{I}^{k}$ may have three values $\left\{-\sqrt{3 h_{n}}, 0, \sqrt{3 h_{n}}\right\}$ with probabilities $1 / 6,2 / 3$ and $1 / 6$ respectively. $\tilde{I}^{k}$ denotes two point distributed random variable $\left\{-\sqrt{h_{n}}, \sqrt{h_{n}}\right\}$ with probabilities $1 / 2$ and $1 / 2$ respectively.

\section{ANALYSIS OF IMPLEMENTATION DIFFICULTIES OF STOCHASTIC RUNGE-KUTTA NUMERICAL METHODS}

As can be seen from the formulas, stochastic Runge-Kutta methods are much more complicated than their classical analogues. In addition to the cumbersome formulas, we can highlight the following factors that complicate the implementation stochastic methods in software, as well as their application to the numerical solution of SDEs.

- When choosing a particular method, it is necessary to consider what type of convergence is necessary to provide for this particular problem, as well as which of the stochastic equations should be solved - in Ito or Stratonovich form. This increases the number of algorithms one has to implement.

- For methods with strong convergence of greater then one at each step it is necessary to solve the resource-intensive problem of stochastic integrals approximation.

- In the numerical scheme, there are not only matrices and vectors, but also tensors (four-dimensional arrays) with which it is necessary to perform a convolution operation on several indexes. The implementation of convolution via summation using normal cycles results in a significant performance drop. 
- Weak methods requires the Monte Carlo and, therefore, a large number of repeated computations of the numerical solution. Since the Monte Carlo method converges approximately as $1 / \sqrt{N}$, where $n$ - number of calculations, to achieve an accuracy of at least $10^{-3}$, it is necessary to perform minimum $10^{6}$ tests.

The most significant performance drop occurs when implementing a universal algorithm, that is, a program that can make a calculation using an arbitrary coefficient table. In this case, we have to use a large number of nested loops in order to organize the summation. The presence in the schemes of double sums and complex combination of indices in the multipliers under the sign of these sums complicates complicates the implementation even more and the number of nested cycles increases to six. In addition to these specific features, we mention a few reasons for the performance drop, which also take place in case of deterministic numerical methods. The obvious way to store the coefficients of the methods is to use arrays. However, in explicit methods that we consider, the matrix is lower-diagonal and storing it as a two-dimensional array results in more than half of the allocated memory being spent on storing zeros.

If you examine the source codes of popular routines that implement classical explicit embedded Runge-Kutta methods, one may find that these programs use a set of named constants rather than arrays to store the coefficients of the method. It is also caused by the fact that the operations with scalar variables in most programming languages are faster than operations on arrays.

We wish to preserve the requirement of code universality and at the same time to increase the speed of calculations and reduce the memory consumption. That led us to automatic code generation from one template.

In addition to performance gains, automatic code generation allows you to add or modify all functions at once by editing only one template. This allows both to reduce the number of errors and to generate different variants of functions for different purposes.

\section{AUTOMATIC CODE GENERATION}

For code generation we use Python 3 language. The program is open source and available on bitbucket repository by URL bitbucket.org/mngev/sde_num_generation. The repository contains module stochastic. This module implements Wiener stochastic process and the numerical methods we considered in this paper. Most part of the module's code are generated by scripts from generator directory.

For the the code generation, we used Jinja2 [4] template engine. This library was originally developed to generate HTML pages, but it has a very flexible syntax and can be used as a universal tool for generating text files of any kind, including source codes in any programming languages. In addition to Jinja2, we also used NumPy library to work with arrays and speed-up some calculations.

In addition to the two external libraries listed above, the standard fraction module was used. It allows to specify the coefficients of the method as rational fractions, and then convert them to float type with the desired order of accuracy. Also we use typing module to annotate the types of function arguments (Python 3.5 and above feature).

Templates are files with Python source code with insertions of Jinja2 specific commands. Information about the coefficients of the methods is stored separately, in a structured form of JSON format. This makes it easy to add new methods and modify old ones by editing JSON files. Currently we use methods with coefficients presented in [9, 13, 14].

Python itself is used as the language for already generated functions with the active use of NumPy library, which allows to get acceptable performance. However, the generated code can be easily reformatted to match the syntax of any other programming language. We plan to modify the program to generate code in Julia language (julialang.org). This language was introduced in 2012 and initially focused on scientific computing. Currently, he is intensively developing and gaining popularity. To date, the current version is 0.6.2. Julia provides performance comparable to $\mathrm{C}++$ and Fortran, but it is a dynamic language with interactive command line (REPL) capability similar to IPython and can be integrated into an interactive Jupyter environment.

The current version of the library exceeds the one described by the authors in [1]. The use of auto-generation made it possible not to use nested loops, which reduced the number of memory allocations, and greatly simplified the code.

\section{A. Realisation of automatic code generation}

To study the calculation errors and the efficiency of different stochastic numerical methods, it is necessary to have a universal implementation of such methods. The universality means the possibility to use any stochastic method with a desired strong or weak error by setting its coefficient table. With direct transfer of mathematical formulas to the program code, one need to use about five nested cycles, which extremely reduces performance, since such code does not take into account a large number of zeros in the coefficient tables and arithmetic operations on zero components are still performed, although this is an extra waste of processor time. 
One way to achieve versatility and acceptable performance is to generate code for a numerical method step. This approach minimizes the number of arithmetic operations and saves memory, since the zero coefficients of the method do not have to be stored.

We implemented a code generator for the three stochastic numerical methods mentioned above:

- scalar method with strong convergence $p_{s}=1.5$,

- vector method with strong convergence $p_{s}=1.0$,

- vector method with weak convergence of $p_{s}=2.0$.

We use Python to implement the code generator and Jinja2 [4] template engine. This template engine was originally created to generate HTML code, but its syntax is universal and allows you to generate text of any kind without reference to any programming or markup language.

Information about the coefficients of each particular method is stored as a JSON file of the following structure:

\{

"name": "method's name (the future name of the function)",

"description": "method's short description",

"stage": 4 ,

"det_order": "2.0",

"stoch_order": "1.5",

"AO": [...],

"BO" : $[\ldots]$,

"A1": [...],

"B1": [

["0", "0", "0", "0"],

["1/2", "0", "0", "0"],

["-1", "0", "0", "0"],

],

["-5", "3", "1/2", "0"]

"c0": ["0", "3/4", "0", "0"],

"c1": ["0", "1/4", "1", "1/4"],

"a": ["1/3", "2/3", "0", "0"],

"b1": ["-1", "4/3", "2/3", "0"],

"b2": ["-1", "4/3", "-1/3", "0"],

"b3": ["2", "-4/3", "-2/3", "0"],

"b4": ["-2", "5/3", "-2/3", "1"]

The parameter stage is the number of method's stages, det_order is the error order of the deterministic part $\left(p_{d}\right)$, stoch_order is the error order of the stochastic part $\left(p_{s}\right)$, name is the name of the method, which will then be used to create the name of the generated function, so it should be written in one word without spaces. All other parameters are the coefficients of the method. In this case, we give the coefficients of the scalar method with strong convergence $p_{s}=1.5$, omitting the coefficients $\mathbf{a}_{0}, \mathbf{a}_{1}$ and $\mathbf{B}_{0}$ to save text space. It is necessary to note that the values of the coefficients can be specified in the form of rational fractions, for which they should be presented as JSON strings and enclosed in double quotes.

For internal representation of stochastic numerical methods we created three Python classes: ScalarMethod, StrongVectorMethod and WeakVectorMethod. The implementation of these classes is contained in the file coefficients_table.py. The constructors of these classes read the JSON file and, based on them, create objects, which can later be used for code generation. The Fraction class from the Python standard library is used to represent rational coefficients. Each class has a method that generates a coefficient table in $\mathrm{LT}_{\mathrm{E}} \mathrm{X}$ format.

The file stoch_rk_generator.py is a script which handles the jinja2 templates and, based on them, generates a code of python functions. For vector stochastic methods, a code is generated for dimensions up to 6 . Functions are named based on the information specified in JSON files, such as strong_srk1w2, strong_srk2w5, weak_srk2w6, and so on.

In addition to the code in Python, $\mathrm{LT}_{\mathrm{E} X} \mathrm{X}$ formulas are generated. It allows one to check the correctness of the generator. For example, we give below the formula generated automatically based on the data from JSON file for Runge-Kutta method strong_srk1w2 with stages $s=3$, and 2 dimensioned Wiener process. Nonzero coefficients of the method are as follows:

$$
A_{01}^{2}=1, A_{11}^{2}=1, A_{11}^{3}=1, B_{11}^{2}=1, B_{11}^{3}=-1,
$$




$$
a_{1}=1 / 2, a_{2}=1 / 2, c_{0}^{2}=1, c_{1}^{2}=1, c_{1}^{3}=1, b_{1}^{1}=1, b_{2}^{2}=1 / 2, b_{3}^{2}=-1 / 2 .
$$

The numerical scheme formulas are quite cumbersome, despite the large number of zeros in the coefficient table:

$$
\begin{gathered}
X^{01 \alpha}=x_{n}^{\alpha}, X^{11 \alpha}=x_{n}^{\alpha}, X^{21 \alpha}=x_{n}^{\alpha}, \\
X^{02 \alpha}=x_{n}^{\alpha}+h_{n}\left[A_{01}^{2} f^{\alpha}\left(t_{n}, X^{01 \beta}\right)\right], \\
X^{12 \alpha}=x_{n}^{\alpha}+h_{n}\left[A_{11}^{2} f^{\alpha}\left(t_{n}, X^{01 \beta}\right)\right] \\
+B_{11}^{2} G_{1}^{\alpha}\left(t_{n}, X^{11 \beta}\right) \frac{I^{11}\left(h_{n}\right)}{\sqrt{h_{n}}}+B_{11}^{2} G_{2}^{\alpha}\left(t_{n}, X^{21 \beta}\right) \frac{I^{21}\left(h_{n}\right)}{\sqrt{h_{n}}}, \\
X^{22 \alpha}=x_{n}^{\alpha}+h_{n}\left[A_{11}^{2} f^{\alpha}\left(t_{n}, X^{01 \beta}\right)\right] \\
+B_{11}^{2} G_{1}^{\alpha}\left(t_{n}, X^{11 \beta}\right) \frac{I^{12}\left(h_{n}\right)}{\sqrt{h_{n}}}+B_{11}^{2} G_{2}^{\alpha}\left(t_{n}, X^{21 \beta}\right) \frac{I^{22}\left(h_{n}\right)}{\sqrt{h_{n}}}, \\
X^{13 \alpha}=x_{n}^{\alpha}+h_{n}\left[A_{11}^{3} f^{\alpha}\left(t_{n}, X^{01 \beta}\right)\right] \\
+B_{11}^{3} G_{1}^{\alpha}\left(t_{n}, X^{11 \beta}\right) \frac{I^{11}\left(h_{n}\right)}{\sqrt{h_{n}}}+B_{11}^{3} G_{2}^{\alpha}\left(t_{n}, X^{21 \beta}\right) \frac{I^{21}\left(h_{n}\right)}{\sqrt{h_{n}}}, \\
X^{23 \alpha}=x_{n}^{\alpha}+h_{n}\left[A_{11}^{3} f^{\alpha}\left(t_{n}, X^{01 \beta}\right)\right] \\
++B_{11}^{3} G_{1}^{\alpha}\left(t_{n}, X^{11 \beta}\right) \frac{I^{12}\left(h_{n}\right)}{\sqrt{h_{n}}}+B_{11}^{3} G_{2}^{\alpha}\left(t_{n}, X^{21 \beta}\right) \frac{I^{22}\left(h_{n}\right)}{\sqrt{h_{n}}}, \\
x_{n+1}^{\alpha}=x_{n}^{\alpha}+h_{n}\left[a_{1} f^{\alpha}\left(t_{n}, X^{01 \beta}\right)+a_{2} f^{\alpha}\left(t_{n}+c_{0}^{2} h_{n}, X^{02 \beta}\right)\right]+b_{1}^{1} I^{1}\left(h_{n}\right) G_{1}^{\alpha}\left(t_{n}, X^{11 \beta}\right) \\
+b_{2}^{2} \sqrt{h_{n}} G_{1}^{\alpha}\left(t_{n}+c_{1}^{2} h_{n}, X^{12 \beta}\right)+b_{3}^{2} \sqrt{h_{n}} G_{1}^{\alpha}\left(t_{n}+c_{1}^{3} h_{n}, X^{13 \beta}\right) \\
+b_{1}^{1} I^{2}\left(h_{n}\right) G_{2}^{\alpha}\left(t_{n}, X^{21 \beta}\right)+b_{2}^{2} \sqrt{h_{n}} G_{2}^{\alpha}\left(t_{n}+c_{1}^{2} h_{n}, X^{22 \beta}\right) \\
\end{gathered}
$$

\section{PARALLEL SDE INTEGRATION WITH WEAK NUMERICAL METHODS}

Stochastic numerical methods with strong convergence are well suited for computing a specific trajectory of SDE solution. If we are not interested in a specific trajectory, but in some probabilistic characteristics (distribution of a random process, mathematical expectation, variance, etc.), then we should use numerical methods with weak convergence.

In the case of numerical methods with weak convergence, we have to use Monte Carlo method. It means that we should solve our SDE system multiple times and each time with different trajectory. The error of the Monte Carlo method depends on the number of trials $N$ as $\sqrt{N}$, so to achieve the accuracy of $10^{-3}$ we need $10^{6}$ trials. However, since the trajectories of the Wiener process are independent, the SDE for each specific trajectory can be solved independently in parallel mode.

We have implemented a script in Python, which allows to find solutions of SDE for $N$ different trajectories in parallel mode by spawning a given number of processes. For processes spawning we use multiprocessing module. The following features of the Cpython interpreter should be noted.

- Because of the global interpreter lock (GIL), it is not possible to use threads for the Monte Carlo method. The standard threading module is only suitable for asynchronous tasks.

- When using processes, you should reinitialize the random number generator with new seed for each process separately, because otherwise all generated processes will generate the same sequence of random numbers.

The source code of the implemented script is located in the tests directory. It is based on two functions.

- Function calculation performs the necessary calculations for a given number of trajectories. As arguments, the function takes the drift vector, the diffusion matrix, the required number of simulations, the initializing value for the random generator, the initial value of the SDU solution, the number of steps of the Wiener process, the time interval at which it is necessary to carry out integration, the dimension of the Wiener process and optionally the function for testing the obtained solution for adequacy. 
- Function run_parallel distributes the Monte Carlo tests equally between processes, creates a pool of processes, and runs them. Each process performs the function calculation.

When carrying out a large number of tests, the storage of all the resulting trajectories requires a significant amount of RAM. Therefore, it is more reasonable to immediately decide what probabilistic characteristics we need and calculate them using on-line algorithms. For example, to calculate the average trajectory, we use the following formula

$$
\overline{\mathbf{x}}_{n}=\overline{\mathbf{x}}_{n-1}+\frac{\mathbf{x}_{n}-\overline{\mathbf{x}}_{n-1}}{n} .
$$

This formula allows you to update the mean values of all path steps $\overline{\mathbf{x}}_{n}$ based on the previous mean values $\overline{\mathbf{x}}_{n-1}$ and the current value $\mathbf{x}_{n}$. As a result, each process must store only one array of constant length, which saves memory.

\section{CONCLUSION}

Stochastic numerical schemes with convergence order higher than 0.5 are considered. It is shown that such methods are much more complicated than equivalent numerical methods for systems of ordinary differential equations. Their specifics makes efficient software implementation of such methods not a trivial task. We discuss an approach based on automatic generation of code, which allows to obtain an efficient implementation of the methods and gives the possibility to use any table of coefficients. We also give a short description of our program and a provide url link to the repository with the source code.

\section{ACKNOWLEDGMENTS}

The publication has been prepared with the support of the "RUDN University Program 5-100" and funded by Russian Foundation for Basic Research (RFBR) according to the research project No 16-07-00556.

[1] M. N. Gevorkyan, T. R. Velieva, A. V. Korolkova, D. S. Kulyabov, L. A. Sevastyanov, Stochastic Runge-Kutta Software Package for Stochastic Differential Equations, in: Dependability Engineering and Complex Systems, Vol. 470, Springer International Publishing, 2016, pp. 169-179. arXiv:1606.06604, doi:10.1007/978-3-319-39639-2_15.

[2] G. Rossum, Python reference manual, Tech. rep., Amsterdam, The Netherlands, The Netherlands (1995). URL https://docs.python.org/3/

[3] E. Jones, T. Oliphant, P. Peterson, et al., SciPy: Open source scientific tools for Python, [Online; accessed 08.10.2017] (2001). URL http://www.scipy.org/

[4] Jinja2 official site. URL http://http://jinja.pocoo.org

[5] G. N. Milstein, Approximate Integration of Stochastic Differential Equations, Theory Probab. Appl. (19) (1974) 557-562.

[6] G. N. Milstein, A Method of Second-Order Accuracy Integration of Stochastic Differential Equations, Theory Probab. Appl. (23) (1979) 396-401.

[7] G. N. Milstein, Weak Approximation of Solutions of Systems of Stochastic Differential Equations, Theory Probab. Appl. (30) (1986) 750-766.

[8] L. Bachelier, Théorie de la spéculation, Annales Scientifiques de l'École Normale Supérieure 3 (17) (1900) $21-86$.

[9] P. E. Kloeden, E. Platen, Numerical Solution of Stochastic Differential Equations, 2nd Edition, Springer, Berlin Heidelberg New York, 1995.

[10] A. Rößler, Runge-Kutta Methods for the Numerical Solution of Stochastic Differential Equations, Ph.D. thesis, Technischen Universität Darmstadt, Darmstadt (februar 2003).

[11] J. Butcher, Numerical Methods for Ordinary Differential Equations, 2nd Edition, Wiley, New Zealand, 2003.

[12] E. Hairer, S. P. Nørsett, G.Wanner, Solving Ordinary Differential Equations I, 2nd Edition, Springer, Berlin, 2008.

[13] K. Debrabant, A. Rößler, Continuous weak approximation for stochastic differential equations, Journal of Computational and Applied Mathematics (214) (2008) 259-273.

[14] K. Debrabant, A. Rößler, Classification of Stochastic Runge-Kutta Methods for the Weak Approximation of Stochastic Differential Equations, arXiv:1303.4510v1 (Mar 2013).

[15] A. Rößler, Strong and Weak Approximation Methods for Stochastic Differential Equations - Some Recent Developments (2010).

[16] G. Maruyama, Continuous Markov processes and stochastic equations, Rendiconti del Circolo Matematico (4) (1955) 48-90.

[17] W. Rümelin, Numerical treatment of stochastic differential equations, SIAM J. Numer. Anal. 19 (3) (1982) 604-613. 
[18] E. Platen, Beiträge zur zeitdiskreten Approximation von Itoprozessen., Ph.D. thesis, Akad. der Wiss., Berlin (1984).

[19] K. Burrage, P. M. Burrage, High strong order explicit Runge-Kutta methods for stochastic ordinary differential equations, Appl. Numer. Math. (22) (1996) 81-101.

[20] K. Burrage, P. M. Burrage, J. A. Belward, A bound on the maximum strong order of stochastic Runge-Kutta methods for stochastic ordinary differential equations., BIT (37) (1997) 771-780.

[21] K. Burrage, P. M. Burrage, General order conditions for stochastic Runge-Kutta methods for both commuting and non-commuting stochastic ordinary differential equation systems, Appl. Numer. Math. (28) (1998) $161-177$.

[22] P. M. Burrage, Runge-Kutta Methods for Stochastic Differential Equations, Ph.D. thesis, University of Qeensland, Australia (1999).

[23] K. Burrage, P. M. Burrage, Order conditions of stochastic Runge-Kutta methods by B-series, SIAM J. Numer. Anal. (38) (2000) 1626-1646.

[24] A. R. Soheili, M. Namjoo, Strong approximation of stochastic differential equations with Runge-Kutta methods, World Journal of Modelling and Simulation 4 (2) (2008) 83-93.

[25] Y. Komori, T. Mitsuri, Stable ROW-Type Weak Scheme for Stochastic Differential Equations, RIMS Kokyuroku (932) (1995) 29-45.

[26] V. Mackevičius, Second-order weak approximations for stratonovich stochastic differential equations, Lithuanian Mathematical Journal 34 (2) (1994) 183-200. doi:10.1007/BF02333416.

[27] A. Tocino, R. Ardanuy, Runge-Kutta methods for numerical solution of stochastic differential equations, Journal of Computational and Applied Mathematics (138) (2002) 219-241.

[28] K. Burrage, P. M. Burrage, Low rank runge-kutta methods, symplecticity and stochastic hamiltonian problems with additive noise, Journal of Computational and Applied Mathematics 236 (16) (2012) 3920-3930. doi:10.1016/j.cam.2012.03.007.

[29] Q. Ma, X. Ding, Stochastic symplectic partitioned runge-kutta methods for stochastic hamiltonian systems with multiplicative noise, Applied Mathematics and Computation 252 (2015) 520-534. doi:10.1016/j.amc.2014.12.045.

[30] W. Zhou, J. Zhang, J. Hong, S. Song, Stochastic symplectic runge-kutta methods for the strong approximation of hamiltonian systems with additive noise, Journal of Computational and Applied Mathematics 325 (2017) 134-148. doi: 10.1016/j.cam.2017.04.050.

[31] S. Amiri, S. M. Hosseini, Stochastic runge-kutta rosenbrock type methods for sde systems, Applied Numerical Mathematics 115 (2017) 1-15. doi:10.1016/j.apnum.2016.11.010.

[32] B. Øksendal, Stochastic differential equations. An introduction with applications, 6th Edition, Springer, Berlin Heidelberg New York, 2003.

[33] M. Wiktorsson, Joint characteristic function and simultaneous simulation of iterated Itô integrals for multiple independent Brownian motions, The Annals of Applied Probability 11 (2) (2001) 470-487. 


\section{Трудности при реализации стохастических численных методов Рунге-Кутты}

М. Н. Геворкян, ${ }^{1, *}$ А. В. Демидова, ${ }^{1, \dagger}$ А. В. Королькова, ${ }^{1, \ddagger}$ и Д. С. Кулябов ${ }^{1,2, \S}$

${ }^{1}$ Кафедра прикладной информатики и теории вероятностей, Российский университет дружбы народов, 117198, Москва, ул. Миклухо-Маклал, д. 6

2 Лаборатория информационных технологий, Объединённый институт ядерных исследований, ул. Жолио-Кюри 6, Дубна, Московская область, Россия, 141980

В данной статье рассматриваются стохастические численные методы типа Рунге-Кутты с слабой и сильной сходимостями для систем стохастических дифференциальных уравнений в форме Ито. Даётся краткий обзор основных стохастических численных методов и сведений из теории стохастических дифференциальных уравнений. Далее излагается и мотивируется подход к реализации данных методов с помощью генерации исходного кода. Обсуждаются детали реализации и используемые языки программирования и библиотеки.

Ключевыеслова: стохастические дифференциальные уравнения, стохастические численные методы, автоматическая генерация кода, Python, Julia, шаблонизатор

\footnotetext{
* gevorkyan-mn@rudn.ru

$\dagger$ demidova-av@rudn.ru

¥ korolkova-av@rudn.ru

§ kulyabov-ds@rudn.ru
} 


\section{I. ВВЕДЕНИЕ}

При моделировании технических систем с управлением возникает необходимость исследования их характеристик. Также необходимо исследование влияния параметров систем на эти характеристики. В системах с управлением возникает такое паразитное явление, как автоколебательный режим. Нами проводились исследования по определению области возникновения автоколебаний. Однако параметры этих автоколебаний нами не исследовались. В данной статье мы предлагаем использовать метод гармонической линеаризации для данной задачи. Этот метод применяется в теории управления, однако данный раздел математики достаточно редко используется в классическом математическом моделировании. Авторы предлагаю методическую статью, призванную познакомить неспециалистов с применением этого метода.

\section{II. ВВЕДЕНИЕ}

В статье авторов [1] описывалась реализация стохастических численных методов типа Рунге-Кутты на языке Python [2] с использованием библиотек NumPy и SciPy [3]. Выбор языка был продиктован удобством программирования и возможностью работать с многомерными массивами как с тензорами (функции tensor_dot и einsum из библиотеки NumPy). Однако производительность созданных функций была на низком уровне, и не столько из-за низкого быстродействия языка Python, сколько из-за большого числа вложенных циклов (до семи циклов). В данной статье мы рассматриваем альтернативных подход к реализации стохастических численных методов, основанный на генерации кода функций.

Данная статья состоит из трех разделов. В первом разделе дается обзор основных источников и излагаются сведения из теории стохастических дифференциальных уравнений (СДУ) и численных методов для их решения. Во втором разделе приведены стохастические численные схемы для скалярных СДУ с сильной сходимостью и для систем СДУ с сильной и слабой сходимостью. Наряду с общими схемами приводятся несколько таблиц коэффициентов, которые позволяют реализовать уже конкретный численный метод. Наконец в третьем разделе мотивируется применение генерации кода для стохастических численных методов и описываются некоторые детали реализованного нами генератора (на языке Python с использованием шаблонизатора Jinja2 [4]).

\section{III. ОБЗОР ОСНОВНЫХ ИСТОчНИКОВ}

Первым, кто использовал стохастические броуновские процессы для математического моделирования был французский математик, ученик А. Пуанкаре Л. Ж.-Б. А. Башелье (1870-1946) в 1900г. в работе [5].

В данном разделе приведем краткий обзор доступных источников, посещенных стохастическим методам Рунге-Кутты. Особо отметим, что такие численные схемы должны быть многостадийными и в них не должно присутствовать частных производных от $\mathbf{f}(t, \mathbf{X})$ и $\mathbf{G}(t, \mathbf{X})$.

В качестве учебника по численным методам решения стохастических дифференциальных уравнений можно указать книгу П. Е. Клодена и Е. Платена [6]. В книге дается краткое введение в теорию стохастических дифференциальных уравнений Ито и Стратоновича и области их применений. Последние две трети книги посвящены изложению численных методов в смысле строгой и слабой аппроксимаций, в том числе излагается и ряд методов Рунге-Кутты.

В качестве краткого введения в предмет можно использовать обзорную статью А. В. Лукшина и С. Н. Смирнова [7], в которой тезисно изложены подходы к численному решению стохастических уравнений по состоянию на 1990 год. В более новой статье [8] А. Ф. Ерешко и Д. В. Филатовой также приведены некоторые численные методы (в том числе и один метод Рунге-Кутты и метод Г. Н. Милштейна [9-11]), а также даны результаты численного эксперимента.

Диссертация А. Росслера [12] является последовательным изложением теории стахостических методов РунгеКутты. Автор рассматривает аппроксимацию систем СДУ Ито и Стратоновичав в слабом смысле для скалярного и многомерного процесса Винера. После краткого обзора литературы автор переходит к изложению теории помеченных деревьев, которая используется для вывода условий порядка в случае детерминированных методов Рунге-Кутты (смотри, например, [13-15], и которая была распространена на случай СДУ. Росслер рассматривает слабо сходящиеся стохастические методы Рунге-Кутты для систем СДУ Ито и Стратоновича как для скалярного так и для многомерного процесса Винера. В третьей и пятой части диссертации приведены конкретные реализации явных стохастических численных методов Рунге-Кутты (в том числе и вложенных) для слабой сходимости.

Дальнейшие результаты Росслера изложены в статьях $[16,17]$ в соавторстве с К. Дебрабант. В препринте [17] продолжена классификация стохастических методов Рунге-Кутты со слабой сходимостью на основе условий 
порядка. Приведено несколько конкретных реализаций и даны результаты численных экспериментов. В другом препринте [18] приведены таблицы методов четвертой стадийности и сильного порядка сходимости $p=3.0$.

Первым стохастическим методом Рунге-Кутты можно считать метод Эйлера-Маруйамы, изложенный Маруйамой в статье [19]. Первым же систематическое исследование стохастических численных методов Рунге-Кутты сильного порядка сходимости $p=1.0$ провели В. Рюмелин [20] и Е. Платен в диссертации [21].

Большой вклад внесли П. М. Бурраж и К. Бурраж в серии статей [22-26]. В этих статьях они не только изучили методы сильного порядка $p=1.5$, но также распространили теорию помеченных деревьев на стохастический случай.

B статье R. Soheili и M. Namjoo [27] получены три метода с сильной сходимостью $p=1.0$ и проведено численное сравнение с методом из книги [6].

Одни из первых методов со слабой сходимостью приведены в книге [6]. Дальнейшее развитие они получили в статье Й. Комори и Т. Митсуи [28] и в статье [29]. В статье [30] получены два трехстадийных метода слабой сходимости $p=2.0$, а также проведены численные эксперименты.

Обратим внимание на статьи $[31,32]$ в которых авторы используют классический метод Рунге-Кутты и разложение Ито-Тейлора для построения численной схемы для стохастического дифференциального уравнения, в которую вошли частные производные вектора сноса $\mathbf{f}(t, \mathbf{X})$ и матрицы диффузии $\mathbf{G}(t, \mathbf{X})$. Такие схемы мы в данной статье рассматривать не будем.

В виду крайней сложности дальнейшего повышения порядка точности стохастических численных схем, современные работы в основном концентрируются на получении численных схем для частных случаев СДУ. Можно выделить работы посвященные симплектическим стохастическим численным методам Рунге-Кутта [3335] и неявным схемам, в частности стохастическим аналогам метода Розенброка [36].

Из литературы на русском языке стоит выделить книгу [37] в которой дан обзор большого количества математических моделей на основе стохастических систем уравнений из различных областей естественных наук. Также автор рассматривает вопрос аппроксимации интеграла Ито, и построение ряда численных схем с сильной сходимостью на основе этих аппроксимаций.

\section{IV. СЛУЧАЙНЫЙ ПРОЦЕСС ВИНЕРА И ПРОГРАММНОЕ ГЕНЕРИРОВАНИЕ ЕГО ТРАЕКТОРИЙ}

Случайный процесс $W(t), t \geqslant 0$ называется скалярным процессом Винера если выполняются следующие условия [6,38]:

- $\mathrm{P}\{W(0)=0\}=1$, иначе говоря $W(0)=0$ почти наверное;

- $W(t)$ - процесс с независимыми приращениями, то есть $\left\{\Delta W_{i}\right\}_{0}^{N-1}$ - независимые случайные величины: $\Delta W_{i}=W\left(t_{i+1}\right)-W\left(t_{i}\right)$ и $0 \leqslant t_{0}<t_{1}<t_{2}<\ldots<t_{N} \leqslant T$

- $\Delta W_{i}=W\left(t_{i+1}\right)-W\left(t_{i}\right) \sim \mathcal{N}\left(0, t_{i+1}-t_{i}\right)$ где $0 \leqslant t_{i+1}<t_{i}<T, i=0,1, \ldots, N-1$

Обозначение $\Delta W_{i} \sim \mathcal{N}\left(0, \Delta t_{i}\right)$ говорит о том, что $\Delta W_{i}$ - нормально распределенная случайная величина с математическим ожиданием $\mathbb{E}\left[\Delta W_{i}\right]=\mu=0$ и дисперсией $\mathbb{D}\left[\Delta W_{i}\right]=\sigma^{2}=\Delta t_{i}$.

Винеровский процесс является моделью броуновского движения (хаотического блуждания). Если рассмотреть процесс $W(t)$ в те моменты времени $0=t_{0}<t_{1}<t_{2}<\ldots<t_{N-1}<t_{N}$ когда он испытывает случайные аддитивные изменения, то непосредственно из определения следует:

$$
W\left(t_{1}\right)=W\left(t_{0}\right)+\Delta W_{0}, W\left(t_{2}\right)=W\left(t_{1}\right)+\Delta W_{1}, \ldots, W\left(t_{N}\right)=W\left(t_{N-1}\right)+\Delta W_{N-1},
$$

где $\Delta W_{i} \sim \mathcal{N}\left(0, \Delta t_{i}\right), \forall i=0, \ldots, N-1$.

Если величину $W\left(t_{N}\right)$ записать в виде накопленной суммы приращений:

$$
W\left(t_{n}\right)=W\left(t_{0}\right)+\sum_{i=0}^{n} \Delta W_{i}, \quad n=0, \ldots, N-1,
$$

и учесть, что $\mathbb{E}\left[\Delta W_{i}\right]=0$ и $\mathbb{D}\left[\Delta W_{i}\right]=\Delta t_{i}$, то можно показать, что сумма нормально распределенных случайных чисел $\Delta W_{i}$ также является нормально распределенным случайным числом:

$$
\mathbb{E} \sum_{i=0}^{N} \Delta W_{i}=0, \mathbb{D} \sum_{i=0}^{n} \Delta W_{i}=\sum_{i=0}^{n} \Delta t_{i}=t_{n}-t_{0}, \quad \sum_{i=0}^{n} \Delta W_{i} \sim \mathcal{N}\left(0, t_{n}-t_{0}\right) .
$$


Многомерный винеровский процесс $\mathbf{W}(t): \Omega \times\left[t_{0}, T\right] \rightarrow \mathbb{R}^{m}$ определяют как случайный процесс составленный из совместно независимых одномерных винеровских процессов $W^{1}(t), \ldots, W^{m}(t)$. Приращения $\Delta W_{i}^{\alpha}, \forall \alpha=1, \ldots, m$ являются совместно независимыми нормально распределенными случайными величинами. С другой стороны вектор $\Delta W_{i}^{\alpha}$ можно представить как многомерную нормально распределенную случайную величину с вектором математических ожиданий $\mu=\mathbf{0}$ и диагональной матрицей ковариаций.

В случае многомерного случайного процесса следует сгенерировать уже $m$ последовательностей из $N$ нормально распределенных случайных величин.

\section{V. СТОХАСТИЧЕСКИЕ ИНТЕГРАЛЫ И СДУ ДЛЯ СКАЛЯРНОГО ПРОЦЕССА ВИНЕРА}

Формулировка стохастического дифференциального уравнения начинается с введения операции стохастического интегрирования.

Пусть $g(t, x(t))$ непрерывная скалярная функция, зависящая от случайного процесса $x(t), W(t)-$ процесс Винера, $t \in\left[t_{0}, T\right], 0 \leqslant t_{0}<t_{1}<t_{2}<\ldots<t_{n-1}<t_{n} \leqslant T<\infty-$ разбиение отрезка $\left[t_{0}, T\right]$, тогда

$$
I(\theta)=\int_{t_{0}}^{T} g(t, x(t)) \mathrm{d} W(t)=\underset{n \rightarrow \infty}{\lim .} \sum_{i=0}^{n-1} g\left(\theta t_{i+1}+(1-\theta) t_{i}, \theta x\left(t_{i+1}\right)+(1-\theta) x\left(t_{i}\right)\right)\left(W\left(t_{i+1}\right)-W\left(t_{i}\right)\right)
$$

где $\theta \in[0,1] . I(\theta)$ называется стохастическим интегралом. Строгое обоснование существования данного интеграла для широкого класса функций см. [38, глава 3].

В в физике и прикладной математике нашли применение два частных случая стохастического интеграла:

- интеграл Ито (назван в честь японского математика К. Ито)

$$
I=I(0)=\underset{n \rightarrow \infty}{\lim . \sum_{i=0}^{n-1}} g\left(t_{i}, x\left(t_{i}\right)\right)\left(W\left(t_{i+1}\right)-W\left(t_{i}\right)\right),
$$

- интеграл Cтратоновича (назван в честь советского физика Р. Л. Стратоновича)

$$
I_{0.5}=I(0.5)=\lim _{n \rightarrow \infty} \sum_{i=0}^{n-1} g\left(\frac{t_{i+1}+t_{i}}{2}, \frac{x\left(t_{i+1}\right)+x\left(t_{i}\right)}{2}\right)\left(W\left(t_{i+1}\right)-W\left(t_{i}\right)\right) .
$$

После введения операции стохастического интегрирования, можно записать интегрального уравнения для случайного процесса $x(t)[38]$.

$$
x\left(t_{k}\right)=x\left(t_{0}\right)+\int_{0}^{t} f(\tau, x(\tau)) \mathrm{d} \tau+\underbrace{\int_{0}^{t} g(\tau, x(\tau)) \mathrm{d} W}_{\text {стохастический интеграл }} .
$$

Вышеприведенному интегральному уравнению соответствует стохастическое дифференциальное уравнение (СДУ):

$$
\mathrm{d} x(t)=f(t, x(t)) \mathrm{d} t+g(t, x(t)) \mathrm{d} W
$$

При этом необходимо помнить, что дифференциал типа $\mathrm{d} x$ не является обычным «малым» приращением функции $x(t)$, а является случайной величиной. Фактически СДУ символической записью предела итерационной схемы. Процесс Винера $W(t)$, приращения которого входят в состав СДУ, называется ведущим процессом для данного СДУ (driving process).

\section{VI. СДУ В ФОРМЕ ИТО ДЛЯ МНОГОМЕРНОГО ПРОЦЕССА ВИНЕРА}

Сформулируем определение системы стохастических дифференциальных уравнений. Введем вероятностное пространство $(\Omega, \mathscr{A}, \mathbb{P})$, где $\Omega$ - пространство элементарных событий, $\mathscr{A}$ - сигма-алгебра подмножеств пространства $\Omega, \mathbb{P}$ - вероятностная мера. На отрезке $\left[t_{0}, T\right] \in \mathbb{R}^{1}$ определена переменная $t$ имеющая физический смысл времени. 
Рассмотрим случайный процесс $\mathbf{x}(t)=\left(x^{1}(t), \ldots, x^{d}(t)\right)^{T}$, где $\mathbf{x}(t)$ принадлежит функциональному пространству $\mathrm{L}^{2}(\Omega)$ с нормой $\|\cdot\|$. Будем считать, что случайный процесс $\mathbf{x}(t)$ является решением для стохастического дифференциального уравнения (СДУ) в форме Ито [6, 38]:

$$
\mathbf{x}(t)=\mathbf{f}(t, \mathbf{x}(t)) \mathrm{d} t+\mathbf{G}(t, \mathbf{x}(t)) \mathrm{d} \mathbf{W}
$$

где $\mathbf{W}=\left(W^{1}, \ldots, W^{m}\right)^{T}$ - многомерный винеровский процесс, называемый ведущuм (driver) процессом СДУ. Функция $\mathbf{f}:\left[t_{0}, T\right] \times \mathbb{R}^{d} \rightarrow \mathbb{R}^{d}$ называется вектором сноса, а матричнозначная функция $\mathbf{G}:\left[t_{0}, T\right] \times \mathbb{R}^{d} \times \mathbb{R}^{m} \rightarrow$ $\mathbb{R}^{d} \times \mathbb{R}^{m}$ - матрицей диффузии. Кроме того $\mathbf{f}(t, \mathbf{x}(t))=\left(f^{1}(t, \mathbf{x}), \ldots, f^{d}(t, \mathbf{x})\right)^{T}$, а матрица $\mathbf{G}$ имеет вид:

$$
\mathbf{G}=\left[\begin{array}{cccc}
g_{1}^{1}(t, \mathbf{x}) & g_{2}^{1}(t, \mathbf{x}) & \ldots & g_{m}^{1}(t, \mathbf{x}) \\
g_{1}^{2}(t, \mathbf{x}) & g_{2}^{2}(t, \mathbf{x}) & \ldots & g_{m}^{2}(t, \mathbf{x}) \\
\vdots & \vdots & \ddots & \vdots \\
g_{1}^{d}(t, \mathbf{x}) & g_{2}^{d}(t, \mathbf{x}) & \ldots & g_{m}^{d}(t, \mathbf{x})
\end{array}\right]
$$

То же уравнение можно переписать в индексном виде:

$$
x^{\alpha}(t)=f^{\alpha}\left(t, x^{\gamma}(t)\right) \mathrm{d} t+\sum_{\beta=1}^{m} g_{\beta}^{\alpha}\left(t, x^{\gamma}(t)\right) \mathrm{d} W^{\beta},
$$

где $\alpha, \gamma=1, \ldots, d, \beta=1, \ldots, m$, a $f^{\alpha}\left(t, x^{\gamma}(t)\right)=f^{\alpha}\left(t, x^{1}(t), \ldots, x^{d}(t)\right)$.

На отрезке $\left[t_{0}, T\right]$ введем сетку $t_{0}<t_{1}<\ldots<t_{N}=T$ с шагом $h_{n}=t_{n+1}-t_{n}$, где $n=0, \ldots, N-1$ и максимальный шаг сетки $h=\max \left\{h_{n-1}\right\}_{1}^{N}$. Далее будем полагать, что сетка равномерная, то $h_{n}=h=h_{n}$ const. $\mathbf{x}_{n}$ - сеточная функция, аппроксимирующая случайный процесс $\mathbf{x}(t)$, так что $\mathbf{x}_{0}=\mathbf{x}\left(t_{0}\right), \mathbf{x}_{n} \approx \mathbf{x}\left(t_{n}\right) \forall n=1, \ldots, N$.

\section{VII. ВЫЧИСЛЕНИЕ И АППРОКСИМАЦИЯ КРАТНЫХ ИНТЕГРАЛОВ ИТО СПЕЦИАЛЬНОГО ВИДА}

Здесь мы не будем вдаваться в общую теорию кратных стохастических интегралов Ито, за которой отсылаем читателя к книге [6]. Здесь же рассмотрим кратные интегралы частного вида, которые входят в формулы стохастических численных методов.

В общем случае для конструирования численных схем, порядок сходимости которых был бы больше чем $p=\frac{1}{2}$, необходимо включение в формулы этих схем однократных, двукратных и трехкратных интегралов Ито следующего вида:

$$
\begin{gathered}
I^{\alpha}\left(t_{n}, t_{n+1}\right)=I^{\alpha}\left(h_{n}\right)=\int_{t_{n}}^{t_{n+1}} \mathrm{~d} W^{\alpha}(\tau), \\
I^{\alpha \beta}\left(t_{n}, t_{n+1}\right)=I^{\alpha \beta}\left(h_{n}\right)=\int_{t_{n}}^{t_{n+1}} \int_{t_{n}}^{\tau_{1}} \mathrm{~d} W^{\alpha}\left(\tau_{2}\right) \mathrm{d} W^{\beta}\left(\tau_{1}\right), \\
I^{\alpha \beta \gamma}\left(t_{n}, t_{n+1}\right)=I^{\alpha \beta \gamma}\left(h_{n}\right)=\int_{t_{n}}^{t_{n+1}} \int_{t_{n}}^{\tau_{1}} \int_{t_{n}}^{\tau_{2}} \mathrm{~d} W^{\alpha}\left(\tau_{3}\right) \mathrm{d} W^{\beta}\left(\tau_{2}\right) \mathrm{d} W^{\gamma}\left(\tau_{1}\right),
\end{gathered}
$$

где $\alpha, \beta, \gamma=0 \ldots, m$ и $W^{\alpha}, \alpha=1, \ldots, m$ - компоненты многомерного винеровского процесса. В случае $\alpha, \beta, \gamma=0$, приращение $\mathrm{d} W^{0}(\tau)$ полагается равным $\mathrm{d} \tau$.

Возникает задача выражения этих интегралов через приращения $\Delta W_{n}^{i}=W^{i}\left(t_{n+1}\right)-W^{i}\left(t_{n}\right)$. Несмотря на кажущуюся простоту, сделать это можно далеко не для всех возможных комбинаций индексов. Рассмотрим в начале те случаи, когда аналитическое выражение получить возможно, а затем перейдем к тем случаям, когда приходится прибегать к аппроксимирующим формулам.

В случае однократного интеграла задача тривиальна и аналитическое выражение можно получить для любого индекса $\alpha$ :

$$
I^{0}\left(h_{n}\right)=\Delta t_{n}=h_{n}, \quad I^{\alpha}\left(h_{n}\right)=\Delta W_{n}^{\alpha}, \alpha=1, \ldots, m
$$


В случае двукратного интеграла $I^{\alpha \beta}\left(h_{n}\right)$ точная формула имеет место лишь при $\alpha=\beta$ :

$$
I^{00}\left(h_{n}\right)=\frac{1}{2} \Delta t_{n}=\frac{1}{2} h_{n}^{2}, \quad I^{\alpha \alpha}\left(h_{n}\right)=\frac{1}{2}\left(\left(\Delta W_{n}^{\alpha}\right)^{2}-\Delta t_{n}\right), \alpha=1, \ldots, m,
$$

в остальных же случаях при $\alpha \neq \beta$ выразить $I^{\alpha \beta}\left(h_{n}\right)$ через приращения $\Delta W_{n}^{\alpha}$ и $\Delta t_{n}$ в конечном виде не представляется возможным, поэтому остается лишь использовать численную аппроксимацию.

Для смешанного случая $I^{0 \alpha}$ и $I^{\alpha 0}$ в [12] приведены простые формулы следующего вида:

$$
\begin{aligned}
& I^{0 \alpha}\left(h_{n}\right)=\frac{1}{2} h_{n}\left(I^{\alpha}\left(h_{n}\right)-\frac{1}{\sqrt{3}} \zeta^{\alpha}\left(h_{n}\right)\right), \\
& I^{\alpha 0}\left(h_{n}\right)=\frac{1}{2} h_{n}\left(I^{\alpha}\left(h_{n}\right)+\frac{1}{\sqrt{3}} \zeta^{\alpha}\left(h_{n}\right)\right),
\end{aligned}
$$

где $\zeta_{n}^{\alpha} \sim \mathcal{N}\left(0, h_{n}\right)$ многомерные нормально распределенные случайные величины.

Для общего случая $\alpha, \beta=1, \ldots, m$ в книге [6] приведены следующие формулы для аппроксимации двукратного интеграла Ито $I^{\alpha \beta}$ :

$$
\begin{gathered}
I^{\alpha \beta}\left(h_{n}\right)=\frac{\Delta W_{n}^{\alpha} \Delta W_{n}^{\beta}-h_{n} \delta^{\alpha \beta}}{2}+A^{\alpha \beta}\left(h_{n}\right) \\
A^{\alpha \beta}\left(h_{n}\right)=\frac{h}{2 \pi} \sum_{k=1}^{\infty} \frac{1}{k}\left[V_{k}^{\alpha}\left(U_{k}^{\beta}+\sqrt{\frac{2}{h_{n}}} \Delta W_{n}^{\beta}\right)-V_{k}^{\beta}\left(U_{k}^{\alpha}+\sqrt{\frac{2}{h_{n}}} \Delta W_{n}^{\alpha}\right)\right],
\end{gathered}
$$

$V_{k}^{\alpha} \sim \mathcal{N}(0,1), U_{k}^{\alpha} \sim \mathcal{N}(0,1), \alpha=1, \ldots, m ; k=1, \ldots, \infty ; n=1, \ldots, N-$ номер шага численной схемы. Из формул видно, что в случае $\alpha=\beta$ получаем конечное выражение для $I^{\alpha \beta}$, приведенное нами выше. В случае $\alpha \neq \beta$ приходится суммировать бесконечный ряд $A^{\alpha \beta}$. Данный алгоритм дает ошибку аппроксимации порядка $O\left(h^{2} / n\right)$, где $n$ - число оставленных слагаемых бесконечного ряда $A^{i j}$.

В статье [39] предложена матричный вид аппроксимирующих формул. Пусть $\mathbf{1}_{m \times m}, \mathbf{0}_{m \times m}-$ единичная и нулевая матрицы $m \times m$, тогда

$$
\begin{gathered}
\mathbf{I}\left(h_{n}\right)=\frac{\Delta \mathbf{W}_{n} \Delta \mathbf{W}_{n}^{T}-h_{n} \mathbf{1}_{m \times m}}{2}+\mathbf{A}\left(h_{n}\right), \\
\mathbf{A}\left(h_{n}\right)=\frac{h}{2 \pi} \sum_{k=1}^{\infty} \frac{1}{k}\left(\mathbf{V}_{k}\left(\mathbf{U}_{k}+\sqrt{2 / h_{n}} \Delta \mathbf{W}_{n}\right)^{T}-\left(\mathbf{U}_{k}+\sqrt{2 / h_{n}} \Delta \mathbf{W}_{n}\right) \mathbf{V}_{k}^{T}\right),
\end{gathered}
$$

где $\Delta \mathbf{W}_{n}, \mathbf{V}_{k}, \mathbf{U}_{k}$ - независимые нормально распределенные многомерные случайные величины:

$$
\begin{gathered}
\Delta \mathbf{W}_{n}=\left(\Delta W_{n}^{1}, \Delta W_{n}^{2}, \ldots, \Delta W_{n}^{m}\right)^{T} \sim \mathcal{N}\left(\mathbf{0}_{m \times m}, h_{n} \mathbf{1}_{m \times m}\right), \\
\mathbf{V}_{k}=\left(V_{k}^{1}, V_{k}^{2}, \ldots, V_{k}^{m}\right)^{T} \sim \mathcal{N}\left(\mathbf{0}_{m \times m}, \mathbf{1}_{m \times m}\right), \quad \mathbf{U}_{k}=\left(U_{k}^{1}, U_{k}^{2}, \ldots, U_{k}^{m}\right)^{T} \sim \mathcal{N}\left(\mathbf{0}_{m \times m}, \mathbf{1}_{m \times m}\right) .
\end{gathered}
$$

В случае, если язык программирования поддерживает векторизацию действий с многомерными массивами, данные формулы могут обеспечить выигрыш к производительности программы.

Наконец рассмотрим трехкратный интеграл. В единственной численной схеме, в которой он встречается, необходимо уметь вычислять только случай одинаковых индексов $\alpha=\beta=\gamma$. Для данного случая в [12] приведена следующая формула:

$$
I^{\alpha \alpha \alpha}\left(h_{n}\right)=\frac{1}{6}\left(\left(I^{\alpha}\left(h_{n}\right)\right)^{3}-3 I^{0}\left(h_{n}\right) I^{\alpha}\left(h_{n}\right)\right)=\frac{1}{6}\left(\left(\Delta W_{n}^{\alpha}\right)^{3}-3 h_{n} \Delta W_{n}^{\alpha}\right) .
$$

\section{VIII. СЛАБАЯ И СИЛЬНАЯ СХОДИМОСТИ АППРОКСИМИРУЮЩЕЙ ФУНКЦИИ}

Прежде чем переходить к формулировке численных схем, необходимо определить критерий точности аппроксимации моделируемого процесса $\mathbf{x}(t)$ аппроксимирующей сеточной функцией $\mathbf{x}_{n}$. Таких критериев принято выделять два: слабый и сильный. 
Последовательность сеточных аппроксимирующих функций $\left\{\mathbf{x}_{n}\right\}_{1}^{N}$ сходится в сильном смысле с порядком $p$ к решению $\mathbf{x}(t)$ СДУ в момент времени $T$ если существует константа $C>0$ и $\delta_{0}>0$ такая что $\forall h \in\left(0, \delta_{0}\right]$ выполняется условие

$$
\mathbb{E}\left(\left\|\mathbf{x}(T)-\mathbf{x}_{N}\right\|\right) \leqslant C h^{p}
$$

Последовательность сеточных аппроксимирующих функций $\left\{\mathbf{x}_{n}\right\}_{1}^{N}$ сходится в слабом смысле с порядком $p$ к решению $\mathbf{x}(t)$ СДУ в момент времени $T$ если существует константа $C_{F}>0$ и $\delta_{0}>0$ такая что $\forall h \in\left(0, \delta_{0}\right]$ выполняется условие

$$
\left|\mathbb{E}[F(\mathbf{x}(T))]-\mathbb{E}\left[F\left(\mathbf{x}_{N}\right)\right]\right| \leqslant C_{F} h^{p}
$$

Здесь $F \in C_{\mathrm{P}}^{2(p+1)}\left(\mathbb{R}, \mathbb{R}^{d}\right)$ - непрерывный дифференцируемый функционал с полиномиальным ростом.

Если матрица $\mathbf{G}$ обращается в ноль, то условие сильной сходимости равносильно условию сходимости для детерминированного случая. В отличие от детерминированного случая порядок сильной сходимости не обязательно является натуральным числом и может принимать дробно-рациональные значения.

Важно отметить, что выбор типа сходимости зависит от решаемой задачи. Увеличение порядка строгой сходимости ведет к увеличению точности аппроксимации траекторий решения х $(t)$ СДУ. Если же требуется вычислить, например, момент случайного процесса $\mathbf{x}(t)$ или обобщенный функционал вида $\mathbb{E}[F(\mathbf{x}(t))]$, то следует повышать порядок слабой сходимости.

\section{IХ. СТОХАСТИЧЕСКИЕ МЕТОДЫ РУНГЕ-КУТТЫ}

\section{А. Численный метод Эйлера-Маруямы}

Простейшим численным методом для решения как скалярных уравнений, так и систем СДУ, является метод Эйлера-Маруямы, названный так в честь Гиширо Маруямы (Gisiro Maruyama), который распространил классический метод Эйлера для ОДУ на случай СДУ [19]. Метод легко обобщается на случай многомерного винеровского процесса.

$$
\begin{aligned}
& x_{0}^{\alpha}=x^{\alpha}\left(t_{0}\right), \\
& x_{n+1}^{\alpha}=x_{n}^{\alpha}+f^{\alpha}\left(t_{n}, x_{n}^{\alpha}\right) h_{n}+\sum_{\gamma=1}^{d} G_{\beta}^{\alpha}\left(t_{n}, x_{n}^{\gamma}\right) \Delta W_{n}^{\beta} .
\end{aligned}
$$

Как видно из формул на каждом шаге для вычисления следующего значения аппроксимирующей функции требуется лишь соответствующее данному шагу приращение процесса $\Delta W_{n}^{\beta}$. Метод имеет сильный порядок $\left(p_{d}, p_{s}\right)=(1.0,0.5)$. Величина $p_{d}$ обозначает порядок точности детерминированной части численного метода, то есть той точности, которую будет давать численный метод при применении его к уравнению функцией $G\left(t, x^{\alpha}(t)\right) \equiv 0$. Величина $p_{s}$ обозначает порядок приближения стохастической части уравнения.

\section{В. Стохастические методы Рунге-Кутты сильной сходимости $p=1.5$ для одномерного винеровского процесса}

В случае скалярного СДУ вектор сноса $f^{\alpha}\left(t, x^{\gamma}\right)$ и матрица диффузии $G_{\beta}^{\alpha}\left(t, x^{\gamma}\right)$ вырождаются в скалярные функции $f(t, x)$ и $g(t, x)$, а ведущий винеровский процесс $W_{t}^{\beta}$ становится одномерным $W_{t}$. Для такого уравнения можно составить численную схему со сильной сходимостью $p=1.5$ :

$$
\begin{aligned}
& X_{0}^{i}=x_{n}+\sum_{j=1}^{s} A_{0 j}^{i} f\left(t_{n}+c_{0}^{j} h_{n}, X_{0}^{j}\right) h_{n}+\sum_{j=1}^{s} B_{0 j}^{i} g\left(t_{n}+c_{1}^{j} h_{n}, X_{1}^{j}\right) \frac{I^{10}\left(h_{n}\right)}{\sqrt{h_{n}}}, \\
& X_{1}^{i}=x_{n}+\sum_{j=1}^{s} A_{1 j}^{i} f\left(t_{n}+c_{0}^{j} h_{n}, X_{0}^{j}\right) h_{n}+\sum_{j=1}^{s} B_{1 j}^{i} g\left(t_{n}+c_{1}^{j} h_{n}, X_{1}^{j}\right) \sqrt{h_{n}} \\
& x_{n+1}=x_{n}+\sum_{i=1}^{s} a_{i} f\left(t_{n}+c_{0}^{i} h_{n}, X_{0}^{i}\right) h_{n}+
\end{aligned}
$$




$$
+\sum_{i=1}^{s}\left(b_{i}^{1} I^{1}\left(h_{n}\right)+b_{i}^{2} \frac{I^{11}\left(h_{n}\right)}{\sqrt{h_{n}}}+b_{i}^{3} \frac{I^{10}\left(h_{n}\right)}{h_{n}}+b_{i}^{4} \frac{I^{111}\left(h_{n}\right)}{h_{n}}\right) g\left(t_{n}+c_{1}^{i} h_{n}, X_{1}^{i}\right),
$$

где $i, j=1, \ldots, s$ ( $s$ - стадийность численного метода). Обобщенная таблица Бутчера данной схемы имеет вид [18]:

\begin{tabular}{c|c|c|c}
$c_{0}^{i}$ & $A_{0 j}^{i}$ & $B_{0 j}^{i}$ & \\
\hline$c_{1}^{i}$ & $A_{1 j}^{i}$ & $B_{1 j}^{i}$ & \\
\hline & $a_{i}$ & $b_{i}^{1}$ & $b_{i}^{2}$ \\
\hline & & $b_{i}^{3}$ & $b_{i}^{4}$
\end{tabular}

Заметим, что винеровский процесс и его приращения присутствуют в вышеприведенных формулах в неявном виде кратных интегралов Ито: $I^{10}\left(h_{n}\right), I^{1}\left(h_{n}\right), I^{11}\left(h_{n}\right), I^{111}\left(h_{n}\right)$, общие формулы для которых приведены выше. Для скалярного случая они упрощаются:

$$
\begin{aligned}
& I^{1}\left(h_{n}\right)=\Delta W_{n}, \\
& I^{10}\left(h_{n}\right)=\frac{1}{2} h_{n}\left(\Delta W_{n}+\zeta_{n} / \sqrt{3}\right), \\
& I^{11}\left(h_{n}\right)=\frac{1}{2}\left(\left(\Delta W_{n}\right)^{2}-h_{n}\right), \\
& I^{111}\left(h_{n}\right)=\frac{1}{6}\left(\left(\Delta W_{n}\right)^{3}-h_{n} \Delta W_{n}\right),
\end{aligned}
$$

где $\zeta_{n} \sim \mathcal{N}\left(0, h_{n}\right), \sigma=\sqrt{h_{n}}$. В препринте Росслера [18] для данной схемы приведены две таблицы Бутчера для метода четвертой стадийности $s=4$.

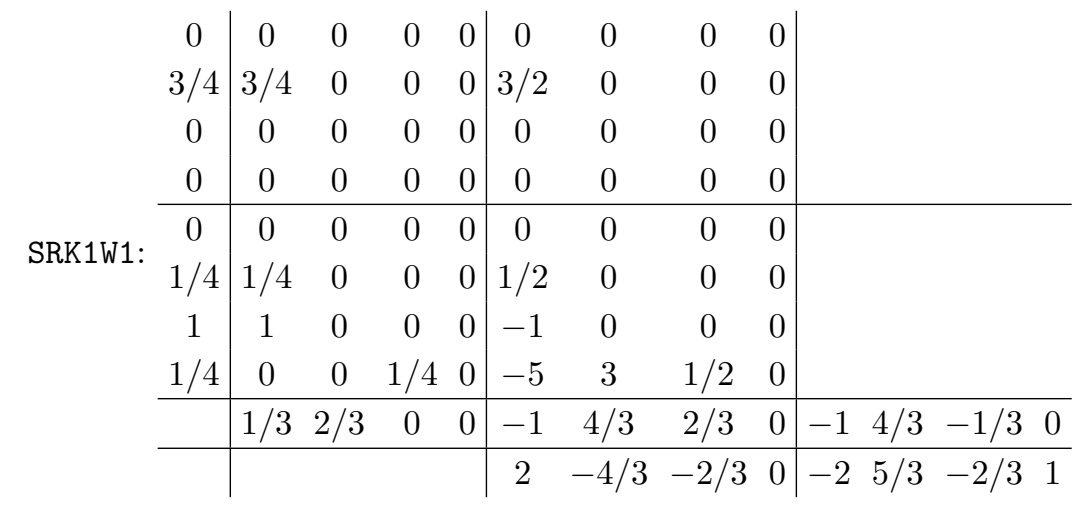

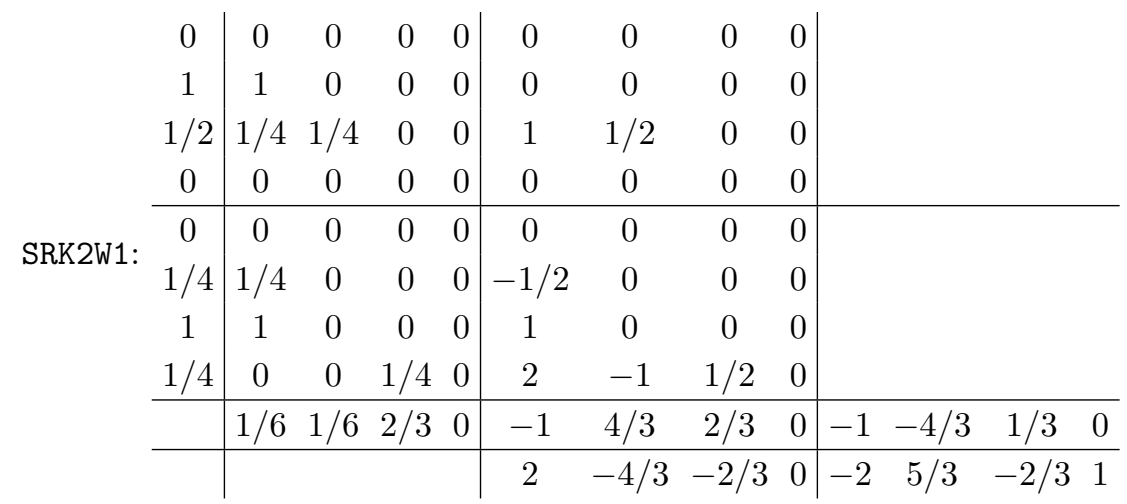

Численную схему реализуемую первой таблицей обозначим как SRK1W1, а вторую как SRK2W2. Mетод SRK1W1 имеет сильный порядок $\left(p_{d}, p_{s}\right)=(2.0,1.5)$, а метод SRK2W1 сильный порядок $\left(p_{d}, p_{s}\right)=(3.0,1.5)$. Еще один метод 
с сильным порядком $p_{s}=1.0$ приведен в книге [6] и его таблица Бутчера имеет вид:

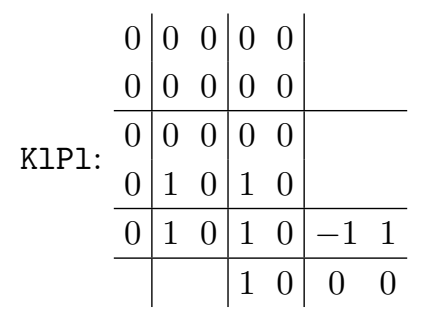

С. Стохастические методы Рунге-Кутты сильной сходимости $p=1.0$ для многомерного винеровского потока

Для системы СДУ Ито с многомерным винеровским процессом можно построить стохастическую численную схему Рунге-Кутты сильного порядка $p_{s}=1.0$ с использованием однократных и двукратных интегралов Ито [18].

$$
\begin{aligned}
& X^{0 i \alpha}=x_{n}^{\alpha}+\sum_{j=1}^{s} A_{0 j}^{i} f^{\alpha}\left(t_{n}+c_{0}^{j} h_{n}, X^{0 j \beta}\right) h_{n}+\sum_{l=1}^{m} \sum_{j=1}^{s} B_{0 j}^{i} G_{l}^{\alpha}\left(t_{n}+c_{1}^{j} h_{n}, X^{l j \beta}\right) I^{l}\left(h_{n}\right), \\
& X^{k i \alpha}=x_{n}^{\alpha}+\sum_{j=1}^{s} A_{1 j}^{i} f^{\alpha}\left(t_{n}+c_{0}^{j} h_{n}, X^{0 j \beta}\right) h_{n}+\sum_{l=1}^{m} \sum_{j=1}^{s} B_{1 j}^{i} G_{l}^{\alpha}\left(t_{n}+c_{1}^{j} h_{n}, X^{l j \beta}\right) \frac{I^{l k}\left(h_{n}\right)}{\sqrt{h_{n}}}, \\
& x_{n+1}^{\alpha}=x_{n}^{\alpha}+\sum_{i=1}^{s} a_{i} f^{\alpha}\left(t_{n}+c_{0}^{i} h_{n}, X^{0 i \beta}\right) h_{n}+\sum_{k=1}^{m} \sum_{i=1}^{s}\left(b_{i}^{1} I^{k}\left(h_{n}\right)+b_{i}^{2} \sqrt{h_{n}}\right) G_{k}^{\alpha}\left(t_{n}+c_{1}^{i} h_{n}, X^{k i \beta}\right),
\end{aligned}
$$

$n=0,1, \ldots, N-1 ; i=1, \ldots, s ; \beta, k=1, \ldots, m ; \alpha=1, \ldots, d$. Обобщенная таблица Бутчера имеет вид [18]:

\begin{tabular}{|c|c|c|c|c|c|c|}
\hline \multirow{6}{*}{ SRK2Wm: } & 0 & 0 & 0 & 0 & $\begin{array}{lll}0 & 0 & 0\end{array}$ & \\
\hline & 1 & 1 & 0 & 0 & $\begin{array}{ll}0 & 0\end{array}$ & \\
\hline & 0 & 0 & 0 & 0 & $\begin{array}{lll}0 & 0 & 0\end{array}$ & \\
\hline & 0 & 0 & 0 & 0 & $\begin{array}{ll}0 & 0\end{array}$ & \\
\hline & 1 & 1 & 0 & 0 & $\begin{array}{lll}1 & 0 & 0\end{array}$ & \\
\hline & 1 & 1 & 0 & 0 & $\begin{array}{lll}-1 & 0 & 0\end{array}$ & \\
\hline
\end{tabular}

$$
\begin{array}{c|c|c|c}
c_{0}^{i} & A_{0 j}^{i} & B_{0 j}^{i} & \\
\hline c_{1}^{i} & A_{1 j}^{i} & B_{1 j}^{i} & \\
\hline & a_{i} & b_{i}^{1} & b_{i}^{2}
\end{array}
$$

В препринте Росслера [18] указаны две таблицы Бутчера для метода третей стадийности $s=3$ :

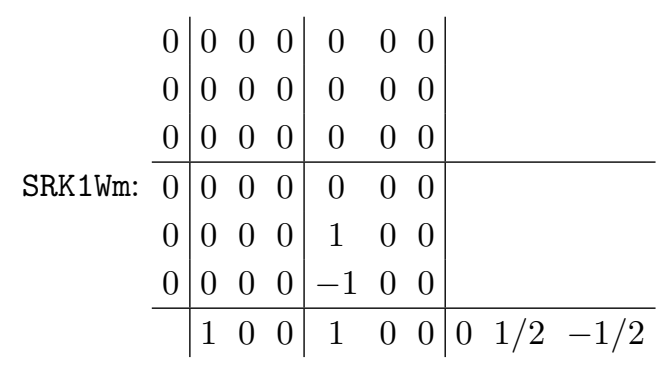

Метод SRK1Wm имеет сильный порядок $\left(p_{d}, p_{s}\right)=(1.0,1.0)$, а метод SRK2Wm сильный порядок $\left(p_{d}, p_{s}\right)=(2.0,1.0)$. 


\section{D. Стохастические методы Рунге-Кутты слабой сходимости $p=2.0$}

Численные методы со слабой сходимостью хорошо аппроксимируют характеристики распределения случайного процесса $x^{\alpha}(t)$. Слабый численный метод не нуждается в информации о траектории ведущего винеровского процесса $W_{n}^{\alpha}$ и случайные величины для этих методов могут быть сгенерированы на другом вероятностном пространстве. Поэтому можно воспользоваться легко моделируемым на компьютере распределением.

$$
\begin{aligned}
& X^{0 i \alpha}=x_{n}^{\alpha}+\sum_{j=1}^{s} A_{0 j}^{i} f^{\alpha}\left(t_{n}+c_{0}^{j} h_{n}, X^{0 j \beta}\right) h_{n}+\sum_{j=1}^{s} \sum_{l=1}^{m} B_{0 j}^{i} G_{l}^{\alpha}\left(t_{n}+c_{1}^{j} h_{n}, X^{l j \beta}\right) \hat{I}^{l}, \\
& X^{k i \alpha}=x_{n}^{\alpha}+\sum_{j=1}^{s} A_{1 j}^{i} f^{\alpha}\left(t_{n}+c_{0}^{j} h_{n}, X^{0 j \beta}\right) h_{n}+\sum_{j=1}^{s} B_{1 j}^{i} G_{k}^{\alpha}\left(t_{n}+c_{1}^{j} h_{n}, X^{k j \beta}\right) \sqrt{h_{n}}, \\
& \widehat{X}^{k i \alpha}=x_{n}^{\alpha}+\sum_{j=1}^{s} A_{2 j}^{i} f^{\alpha}\left(t_{n}+c_{0}^{j} h_{n}, X^{0 j \beta}\right) h_{n}+\sum_{j=1}^{s} \sum_{l=1, l \neq k}^{m} B_{2 j}^{i} G_{l}^{\alpha}\left(t_{n}+c_{1}^{j} h_{n}, X^{l j \beta}\right) \frac{\hat{I}^{k l}}{\sqrt{h_{n}}}, \\
& x_{n+1}^{\alpha}=x_{n}^{\alpha}+\sum_{i=1}^{s} a_{i} f^{\alpha}\left(t_{n}+c_{0}^{i}, X^{0 i \beta}\right) h_{n}+\sum_{i=1}^{m} \sum_{k=1}^{m}\left(b_{i}^{1} \hat{I}^{k}+b_{i}^{2} \frac{\hat{I}^{k k}}{\sqrt{h_{n}}}\right) G_{k}^{\alpha}\left(t_{n}+c_{1}^{i} h_{n}, X^{k i \beta}\right)+ \\
& +\sum_{i=1}^{s} \sum_{k=1}^{m}\left(b_{i}^{3} \hat{I}^{k}+b_{i}^{4} \sqrt{h_{n}}\right) G_{k}^{\alpha}\left(t_{n}+c_{2}^{i} h_{n}, \widehat{X}^{k i \beta}\right)
\end{aligned}
$$

\begin{tabular}{|c|c|c|c|c|c|c|c|c|c|c|c|c|c|c|}
\hline 0 & 0 & 0 & 0 & 0 & 0 & 0 & & 0 & 0 & $\begin{array}{ll}0 & 0\end{array}$ & 0 & 0 & 0 & \\
\hline 1 & 1 & 0 & 0 & $\frac{1}{3}$ & 0 & 0 & & 1 & 1 & $\begin{array}{ll}0 & 0\end{array}$ & 1 & 0 & 0 & \\
\hline$\frac{5}{12}$ & $\frac{25}{144}$ & $\frac{35}{144}$ & 0 & $-\frac{5}{6}$ & 0 & 0 & & 0 & 0 & $\begin{array}{ll}0 & 0\end{array}$ & 0 & 0 & 0 & \\
\hline 0 & 0 & 0 & 0 & 0 & 0 & 0 & & 0 & 0 & $\begin{array}{ll}0 & 0\end{array}$ & 0 & 0 & 0 & \\
\hline$\frac{1}{4}$ & $\frac{1}{4}$ & 0 & 0 & $\frac{1}{2}$ & 0 & 0 & & 1 & & $\begin{array}{ll}0 & 0\end{array}$ & 1 & 0 & 0 & \\
\hline$\frac{1}{4}$ & $\frac{1}{4}$ & 0 & 0 & $-\frac{1}{2}$ & 0 & 0 & & 1 & 1 & $\begin{array}{ll}0 & 0\end{array}$ & -1 & 0 & 0 & \\
\hline 0 & 0 & 0 & 0 & 0 & 0 & 0 & & 0 & 0 & $\begin{array}{ll}0 & 0\end{array}$ & 0 & 0 & 0 & \\
\hline 0 & 0 & 0 & 0 & 1 & 0 & 0 & & 0 & 0 & $\begin{array}{ll}0 & 0\end{array}$ & 1 & 0 & 0 & \\
\hline \multirow[t]{3}{*}{0} & 0 & 0 & 0 & -1 & 0 & 0 & & 0 & 0 & $\begin{array}{ll}0 & 0\end{array}$ & -1 & 0 & 0 & \\
\hline & $\frac{1}{10}$ & $\frac{3}{14}$ & $\frac{24}{35}$ & 1 & -1 & -1 & $\begin{array}{lll}0 & 1 & -1\end{array}$ & & & $\begin{array}{ll}\frac{1}{2} & 0\end{array}$ & $\frac{1}{2}$ & $\frac{1}{4}$ & $\frac{1}{4}$ & $\begin{array}{lll}0 & \frac{1}{2} & -\frac{1}{2}\end{array}$ \\
\hline & & & & $\frac{1}{2}$ & $-\frac{1}{4}$ & $-\frac{1}{4}$ & $0 \quad \frac{1}{2}-\frac{1}{2}$ & & & & $-\frac{1}{2}$ & $\frac{1}{4}$ & $\frac{1}{4}$ & $\begin{array}{lll}0 & \frac{1}{2} & -\frac{1}{2}\end{array}$ \\
\hline
\end{tabular}

Обобщенная таблица Бутчера имеет вид [18]:

$$
\begin{array}{c|c|c|c}
c_{0}^{i} & A_{0 j}^{i} & B_{0 j}^{i} & \\
\hline c_{1}^{i} & A_{1 j}^{i} & B_{1 j}^{i} & \\
\hline c_{2}^{i} & A_{2 j}^{i} & B_{2 j}^{i} & \\
\hline & a_{i} & b_{i}^{1} & b_{i}^{2} \\
\hline & & b_{i}^{3} & b_{i}^{4}
\end{array}
$$

В численной схеме слабого стохастического метода Рунге-Кутты используются следующие случайные величины:

$$
\hat{I}^{k l}=\left\{\begin{array}{l}
\frac{1}{2}\left(\hat{I}^{k} \hat{I}^{l}-\sqrt{h}_{n} \tilde{I}^{k}\right), k<l, \\
\frac{1}{2}\left(\hat{I}^{k} \hat{I}^{l}+\sqrt{h}_{n} \tilde{I}^{l}\right), l<k, \\
\frac{1}{2}\left(\left(\hat{I}^{k}\right)^{2}-h_{n}\right) . k=l .
\end{array}\right.
$$


Величина $\hat{I}^{k}$ имеет трехточечное распределение. Это означает, что $\hat{I}^{k}$ может принимать три значения $\left\{-\sqrt{3 h_{n}}, 0, \sqrt{3 h_{n}}\right\}$ с вероятностями $1 / 6,2 / 3$ и $1 / 6$ соответственно. В свою очередь величина $\tilde{I}^{k}$ имеет двухточечное распределение $\left\{-\sqrt{h_{n}}, \sqrt{h_{n}}\right\}$ с вероятностями $1 / 2$ и $1 / 2$.

\section{Х. АНАЛИЗ ТРУДНОСТЕЙ РЕАЛИЗАЦИИ СТОХАСТИЧЕСКИХ ЧИСЛЕННЫХ МЕТОДОВ РУНГЕ-КУТТЫ}

Как видно уже из формул, стохастические методы Рунге-Кутты значительно сложнее своих классических аналогов. Кроме громоздкости формул, можно выделить еще следующие факторы, усложняющие реализацию стохастических методов в программном виде, а также их применение для численного решения СДУ.

- При выборе конкретного метода надо учитывать какой тип сходимости необходимо обеспечить для данной конкретной задачи, а также какое из стохастических уравнений необходимо решать - в форме Ито или в форме Стратоновича. Это увеличивает количество алгоритмов, которые нужно запрограммировать.

- Для методов с сильной сходимостью большей единицы на каждом шаге необходимо решать ресурсоемкую задачу по аппроксимации двукратных стохастических интегралов.

- В численной схеме присутствуют не только матрицы и векторы, но и тензоры (четырехмерные массивы) с которыми необходимо совершать операцию свертки по нескольким индексам. Реализация свертки через суммирование с помощью обычных циклов приводит к существенному падению производительности.

- Для использования слабых методов необходимо применять метод Монте Карло, проводя несколько серий по множеству испытаний в каждой. Так как метод Монте-Карло сходится приблизительно как $1 / \sqrt{N}$, где $N$ - число испытаний, то для достижения точности хотя бы $10^{-3}$, необходимо провести минимум $10^{6}$ испытаний.

Наиболее существенное падение производительности происходит при реализации универсального алгоритма, то есть такой программы, которая может произвести расчет, используя произвольную таблицу коэффициентов. В этом случае приходится использовать большое количество вложенных циклов, для того, чтобы организовать суммирование. Наличие в схемах для систем СДУ двойных сумм и сложной комбинации индексов в множителях, находящихся под знаком этих сумм, еще более усложняет задачу и число вложенных циклов вырастает до шести. Кроме этих специфических особенностей, стоит упомянуть также несколько причин падения производительности, присущих также и классическим схемам, которые в стохастическом случае также играют роль. Очевидным способом хранения коэффициентов методов является использование массивов. Однако у явных методов, которые мы рассматриваем, матрица является нижне-диагональной и хранение ее в виде двумерного массива приводит к тому, что более чем половина выделенной для массива памяти тратится на хранение нулей.

Если изучить исходные коды популярных подпрограмм, реализующих классические явные вложенные методы Рунге-Кутты, то можно обнаружит, что в этих программах для хранения коэффициентов метода используется набор именованных констант, а не массивов. Это вызвано также и тем, что операции со скалярными величинами в большинстве языков программирования проводятся быстрее, чем операции с массивами.

При сохранении требования универсальности создаваемого кода и вместе с тем желание увеличить скорости вычислений и уменьшить расход памяти, привели нас к решению использовать автоматическую генерацию кода по одному шаблону для каждого отдельного метода.

Кроме выигрыша в производительности, автоматическая генерации кода, позволяет добавлять или изменять все функции за раз путем редактирования одного лишь шаблона, а не каждой отдельной функции. Это позволяет как уменьшить количество ошибок, так и генерировать различные варианты функций для разных целей.

\section{ХІ. КРАТКОЕ ОПИСАНИЕ АВТОМАТИЧЕСКОЙ ГЕНЕРАЦИИ КОДА}

В качестве языка, для написания генератора кода, используется язык Рython. Исходный код и документация созданных в нашем коллективе программ, доступны по ссылке bitbucket.org/mngev/sde_num_generation. Данный репозиторий содержит модуль stochastic, в котором реализован винеровский случайный процесс и численные методы типа Рунге-Кутты для скалярных и многомерных стохастических дифференциальных уравнений в форме Ито. Большая часть кода для этого модуля генерируется набором скриптов из директории generator. В ручную написан класс, реализующий многомерный винеровский процесс и методы Эйлера-Маруямы.

Для работы генератора кода мы использовали библиотеку для обработки шаблонов Јіnја2 [4]. Данный шаблонизатор (template engine) разрабатывался изначально для генерации HTML страниц, однако он обладает 
очень гибким синтаксисом и может использоваться как универсальное средство для генерации текстовых файлов любого вида, в том числе и исходных кодов на любых языках программирования. Кроме Jinja2 мы также использовали библиотеку NumPy для работы с массивами и ускорения вычислений.

Кроме перечисленных выше двух внешних библиотек, был использован стандартный модуль fraction, который позволяет задать коэффициенты метода в виде рациональных дробей, а потом уже преобразовывать их в вещественный вид с нужным порядком точности, а также модуль typing для аннотации типов аргументов функций.

Шаблоны для генерации представляют собой файлы с исходным кодом на языке Python со вставками специальных команд шаблонизатора Jinja2. Информация о коэффициентах методов хранится отдельно, в структурированном виде в формате JSON. Это позволяет легко добавлять новые методы и изменять старые путем редактирования и JSON файлов. В настоящее время генерируются методы с коэффициентами, представленными в работах $[6,16,17]$.

В качестве языка для уже сгенерированных функций используется сам python с активным применением библиотеки NumPy, которая позволяет получить приемлемую производительность. Однако генерируемый код легко можно переформатировать так, чтобы он соответствовал синтаксису любого другого языка программирования. Мы планируем доработать программу, для генерации кода на языке Julia (julialang.org). Данный язык был представлен в 2012 году и изначально ориентирован на научные вычисления. В настоящее время он интенсивно развивается и набирает популярность. На сегодняшний день актуальной является версия 0.6.1. Julia позволяет получить производительность, сравнимую с $\mathrm{C}++$ и Fortran, но при этом является динамическим языком с возможностью интерактивной командной строки (REPL) на подобии IPython и может интегрироваться в интерактивную среду Jupyter. Текущая версия библиотеки превосходит описанную авторами в статье [1]. Применение автогенерации позволило избавится от большого количества вложенных циклов, выделения лишней памяти для хранения нулевых коэффициентов, а также значительно упростило код.

\section{ХІІ. ЗАКЛЮЧЕНИЕ}

В данной работе рассмотрены стохастические численные схемы с порядком сходимости выше 0.5. Показано, что такие методы существенно сложнее эквивалентных численных методов для систем обыкновенных дифференциальных уравнений. Выделены их особенности, делающие эффективную программную реализацию таких методов не тривиальной задачей. В заключительной части статьи обсуждается подход, основанный на автоматической генерации программного кода, который позволяет получить эффективную реализацию рассматриваемых методов, давая возможность использовать любую таблицу коэффициентов. Дано краткое описание программы, созданной авторами и ссылка на репозиторий с исходными кодами.

\section{БЛАГОДАРНОСТИ}

Публикация подготовлена при поддержке Программы РУДН «5-100» и при финансовой поддержке РФФИ в рамках научного проекта № 16-07-00556.

[1] Gevorkyan M. N., Velieva T. R., Korolkova A. V., Kulyabov D. S., Sevastyanov L. A. Stochastic Runge-Kutta Software Package for Stochastic Differential Equations // Dependability Engineering and Complex Systems. - Springer International Publishing, 2016. - Vol. 470. - P. 169-179. - 1606.06604.

[2] Python Reference Manual : Rep. ; Executor: G. Rossum. - Amsterdam, The Netherlands, The Netherlands : 1995. — Access mode: https://docs.python.org/3/.

[3] Jones E., Oliphant T., Peterson P. et al. SciPy: Open source scientific tools for Python. - 2001. - [Online; accessed 08.10.2017]. Access mode: http://www.scipy.org/.

[4] Jinja2 official site. - Access mode: http://http://jinja.pocoo.org.

[5] Bachelier L. Théorie de la spéculation // Annales Scientifiques de l'École Normale Supérieure. — 1900. — Vol. 3, no. 17. — P. 21-86.

[6] Kloeden P. E., Platen E. Numerical Solution of Stochastic Differential Equations. — 2 edition. — Berlin Heidelberg New York : Springer, 1995. - 632 p. - ISBN: 3-540-54062-8.

[7] Лукшин А. В., Смирнов С. Н. Численные методы решения стохастических дифференциальных уравнений // Вычислительные алгоритмы и методы. - 1990. - Т. 2, № 11. - С. 108-121. 
[8] Ерешко А. Ф., Филатова Д. В. Анализ явных численных методов решения стохастических дифференциальных уравнений // Труды ИСА РАН. Динамика неоднородных систем. - 2008. - Т. 32, № 2. - С. 164-173.

[9] Milstein G. N. Approximate Integration of Stochastic Differential Equations // Theory Probab. Appl. — 1974. — no. 19. — P. 557-562.

[10] Milstein G. N. A Method of Second-Order Accuracy Integration of Stochastic Differential Equations // Theory Probab. Appl. - 1979. - no. 23. - P. 396-401.

[11] Milstein G. N. Weak Approximation of Solutions of Systems of Stochastic Differential Equations // Theory Probab. Appl. 1986. - no. 30. - P. 750-766.

[12] Rößler A. Runge-Kutta Methods for the Numerical Solution of Stochastic Differential Equations : Ph. D. thesis / A. Rößler ; Technischen Universität Darmstadt. — Darmstadt, 2003. - februar.

[13] Butcher J. Numerical Methods for Ordinary Differential Equations. — 2 edition. — New Zealand : Wiley, 2003. — 425 p. — ISBN: 0-471-96758-0.

[14] Hairer E., Nørsett S. P., G.Wanner. Solving Ordinary Differential Equations I. — 2 edition. — Berlin : Springer, 2008. — 528 p. - ISBN: 978-3-540-56670-0.

[15] Хайрер Э., Нёрсетт С., Ваннер Г. Решение обыкновенных дифференциальных уравнений. Нежесткие задачи / Под ред. С. С. Филиппова. - 1 изд. - М. : Мир, 1990. - 512 с. - ISBN: 5-03-001179-X.

[16] Debrabant K., Rößler A. Continuous weak approximation for stochastic differential equations // Journal of Computational and Applied Mathematics. - 2008. - no. 214. - P. 259-273.

[17] Debrabant K., Rößler A. Classification of Stochastic Runge-Kutta Methods for the Weak Approximation of Stochastic Differential Equations / Technische Universität Darmstadt, Fachbereich Mathematik. — 2013. — Mar. — arXiv:1303.4510v1.

[18] Rößler A. Strong and Weak Approximation Methods for Stochastic Differential Equations — Some Recent Developments / Department Mathematik. Schwerpunkt Mathematische Statistik und Stochastische Prozesse. — 2010.

[19] Maruyama G. Continuous Markov processes and stochastic equations // Rendiconti del Circolo Matematico. - 1955. no. 4. - P. 48-90.

[20] Rümelin W. Numerical treatment of stochastic differential equations // SIAM J. Numer. Anal. — 1982. — Vol. 19, no. 3. — P. 604-613.

[21] Platen E. Beiträge zur zeitdiskreten Approximation von Itoprozessen. : Ph. D. thesis / E. Platen ; Akad. der Wiss. Berlin, 1984.

[22] Burrage K., Burrage P. M. High strong order explicit Runge-Kutta methods for stochastic ordinary differential equations // Appl. Numer. Math. - 1996. - no. 22. — P. 81-101.

[23] Burrage K., Burrage P. M., Belward J. A. A bound on the maximum strong order of stochastic Runge-Kutta methods for stochastic ordinary differential equations. // BIT. - 1997. - no. 37. - P. 771-780.

[24] Burrage K., Burrage P. M. General order conditions for stochastic Runge-Kutta methods for both commuting and non-commuting stochastic ordinary differential equation systems // Appl. Numer. Math. — 1998. — no. 28. — P. 161-177.

[25] Burrage P. M. Runge-Kutta Methods for Stochastic Differential Equations : Ph. D. thesis / P. M. Burrage ; University of Qeensland. - Australia, 1999.

[26] Burrage K., Burrage P. M. Order conditions of stochastic Runge-Kutta methods by B-series // SIAM J. Numer. Anal. 2000. - no. 38. - P. 1626-1646.

[27] Soheili A. R., Namjoo M. Strong approximation of stochastic differential equations with Runge-Kutta methods // World Journal of Modelling and Simulation. - 2008. - Vol. 4, no. 2. - P. 83-93.

[28] Komori Y., Mitsuri T. Stable ROW-Type Weak Scheme for Stochastic Differential Equations // RIMS Kokyuroku. 1995. - no. 932. - P. 29-45.

[29] Mackevičius V. Second-order weak approximations for stratonovich stochastic differential equations // Lithuanian Mathematical Journal. - 1994. - Vol. 34, no. 2. - P. 183-200.

[30] Tocino A., Ardanuy R. Runge-Kutta methods for numerical solution of stochastic differential equations // Journal of Computational and Applied Mathematics. - 2002. — no. 138. - P. 219-241.

[31] Wilkie J. Numerical Methods for Stochastic Differential Equations / Department of Chemistry, Simon Fraser University, Burnaby. - 2004. - Jul. - arXiv:quant-ph/0407039v1.

[32] Wilkie J., Cetinbas M. Variable-stepsize Runge-Kutta methods for stochastic Schrödinger equations // Physics Letters A. - 2005. - Vol. 337, no. 3. - P. 166-182.

[33] Burrage K., Burrage P. M. Low rank Runge-Kutta methods, symplecticity and stochastic Hamiltonian problems with additive noise // Journal of Computational and Applied Mathematics. - 2012. — Vol. 236, no. 16. - P. 3920-3930.

[34] Ma Q., Ding X. Stochastic symplectic partitioned Runge-Kutta methods for stochastic Hamiltonian systems with multiplicative noise // Applied Mathematics and Computation. - 2015. - Vol. 252. - P. 520-534.

[35] Zhou W., Zhang J., Hong J., Song S. Stochastic symplectic Runge-Kutta methods for the strong approximation of Hamiltonian systems with additive noise // Journal of Computational and Applied Mathematics. — 2017. — Vol. 325. P. 134-148.

[36] Amiri S., Hosseini S. M. Stochastic Runge-Kutta Rosenbrock type methods for SDE systems // Applied Numerical Mathematics. — 2017. - Vol. 115. - P. 1-15.

[37] Кузнецов Д. Ф. Стохастические дифференциальные уравнения: теория и практика численного решения. - 4 изд. Санкт-Петербург : Издательство Политехнического Университета, 2010. - 786 с.

[38] Оксендаль Б. Стохастические дифференциальные уравнения. Введение в теорию и приложения. - 5 изд. - М. : Мир, ACT, 2003. - 385 c. - ISBN: 5-03-003477-3. 
[39] Wiktorsson M. Joint characteristic function and simultaneous simulation of iterated Itô integrals for multiple independent Brownian motions // The Annals of Applied Probability. - 2001. — Vol. 11, no. 2. — P. 470-487. 